\title{
17. NEOGENE AND PALEOCENE-MAESTRICHTIAN CALCAREOUS NANNOFOSSIL STRATIGRAPHY, DEEP SEA DRILLING PROJECT SITES 604 AND 605, UPPER CONTINENTAL RISE OFF NEW JERSEY: SEDIMENTATION RATES, HIATUSES, AND CORRELATIONS WITH SEISMIC STRATIGRAPHY ${ }^{1}$
}

\author{
Thomas H. Lang and Sherwood W. Wise, Jr., Department of Geology, Florida State University²
}

\begin{abstract}
Maestrichtian to Holocene calcareous nannofossils from two closely spaced sites on the upper continental rise some 100 miles $(161 \mathrm{~km})$ southeast of Atlantic City, New Jersey, were zoned in order to help date a major canyon-cutting event in the late Miocene and to delineate and correlate other hiatuses with seismic stratigraphy. Mid-middle Eocene through middle Miocene sediments (Zones CP14 to CN6) were not recovered in these holes, but nearly all other zones are accounted for. The Eocene section is described in a companion chapter (Applegate and Wise, this volume).

Nannofossils are generally sparse and moderately preserved in the clastic sediments of Site 604 . Sedimentation rates are extremely high for the upper Pleistocene ( $201 \mathrm{~m} / \mathrm{m}$.y. minimum) above a hiatus calculated to span 0.44 to $1.1 \mathrm{Ma}$. The associated disconformity is correlated with local seismic reflection Horizon $\mathrm{P}_{1}$. Sedimentation rates continue to be high $(93 \mathrm{~m} / \mathrm{m} . \mathrm{y}$.) down to a second hiatus in the upper Pliocene dated from about 2.4 to 2.9 (or possibly 3.3) Ma. The disconformity associated with this hiatus is correlated with local seismic reflection Horizon $\mathrm{P}_{2}$ and regional Reflector Blue, which can be interpreted to mark either the onset of Northern Hemisphere continental glaciation or circulation changes associated with the closure of the Central American Seaway. Sedimentation rates in the pre-glacial lower Pliocene are only about a third those in the glacial upper Pliocene.

A prominent disconformity in the upper Miocene marks a major lithologic boundary that separates Messinian(?) glauconitic claystones above from lower Tortonian conglomeratic debris flows and turbidites below. The debris flows recovered are assigned to nannofossil Zones $\mathrm{CN} 8 \mathrm{a}$ and $\mathrm{CN} 7$, but drilling difficulties prevented penetration of the bottom of this sequence some $100 \mathrm{~m}$ below the terminal depth of the hole. Correlation of the lower bounding seismic reflector $\left(\mathrm{M}_{2} / \mathrm{Merlin}\right.$ ?) to a drift sequence drilled on the lower rise at DSDP Site 603 , however, predicts that the debris flows began close to the beginning of the late Miocene (upper Zone CN6 time) at about $10.5 \mathrm{Ma}$. The debris flows represent a major canyon-cutting event that we correlate with the beginning of the particularly severe late Miocene glaciations believed to be associated with the formation of the West Antarctic Ice Sheet. The existence of these spectacular debris flows strongly suggest that the late Miocene glacio-eustatic low stand occurred during Vail Cycle TM3.1 (lower Tortonian) rather than during Vail Cycle TM3.2 (Messinian) as originally published.

Beneath a set of coalesced regional disconformities centered upon seismic reflection Horizon $\mathrm{A}^{\mathrm{u}}$, coccoliths are abundant and in general are moderately preserved at Site 605 in a $619-\mathrm{m}$ carbonate section extending from the middle Eocene Zone CP13b to the upper Maestrichtian Lithraphidites quadratus Zone. Sedimentation rates are $37 \mathrm{~m} / \mathrm{m} . \mathrm{y}$. in the Eocene down to a condensed interval near the base (Zone CP9). A disconformity is suspected near the Eocene/Paleocene boundary. Sedimentation rates for the upper Paleocene Zone CP8 are similar to those of the Eocene, but Zones CP7 and CP6 lie within another condensed interval. The highest Paleocene rates are $67 \mathrm{~m} / \mathrm{m}$.y. down through Zones CP5 and CP4 to a major disconformity that separates the upper Paleocene from the Danian. This hiatus spans about 2.6 m.y. (upper Zone CP3 to lower Zone CP2) and corresponds to the major sea-level drop at the base of Vail Cycle TE2.1. As the most prominent break in this Paleogene section, it may correspond to seismic reflection Horizon $\mathrm{A}^{*}$ of the North American Basin. Sedimentation rates from this point to the Cretaceous/Tertiary boundary drop to $11 \mathrm{~m} /$ m.y., still high for a Paleocene DSDP section. No major break in deposition could be detected at the Cretaceous/Tertiary boundary.
\end{abstract}

\section{INTRODUCTION}

The locations of Deep Sea Drilling Project Sites 604 and 605 on the upper continental rise some 100 miles southeast of Atlantic City, New Jersey (Figs. 1 and 2), were planned as part of the New Jersey Transect, a series of DSDP holes that would link commercial petroleum exploration and test wells on the continental shelf with DSDP holes on the lower continental rise. This would

\footnotetext{
1 van Hinte, J. E., Wise, S. W., Jr., et al., Init. Repts. DSDP, 93: Washington (U.S. Govt, Printing Office).

2 Addresses: (Lang, present address) Flight Squadron VF 211, USS Kitty Hawk, San Diego, CA; (Wise) Dept. of Geology, Florida State University, Tallahassee, FL 32306. Please send reprint requests to second author.
}

provide the first downdip transect of a passive continental margin from the coastal plain to the abyssal plain. DSDP Holes 604 and 604A penetrated $285 \mathrm{~m}$ to the upper Miocene where they were terminated prematurely in turbidite sands and debris flows. Hole 605 , on the other hand, reached middle Maestrichtian carbonates at 816.7 $m$ (Figs. 3 and 4).

We report here the calcareous nannofossil biostratigraphy of the Neogene and of the Paleocene to Maestrichtian units. For Hole 605, coccoliths within the intervening $366 \mathrm{~m}$ of Eocene carbonate are discussed by Applegate and Wise (this volume). We describe our assemblages from the top of each section down beginning with Site 604. Of particular interest are the debris flows at Site 604 and the expanded (196 m) Paleocene section 
T. H. LANG, S. W. WISE, JR.

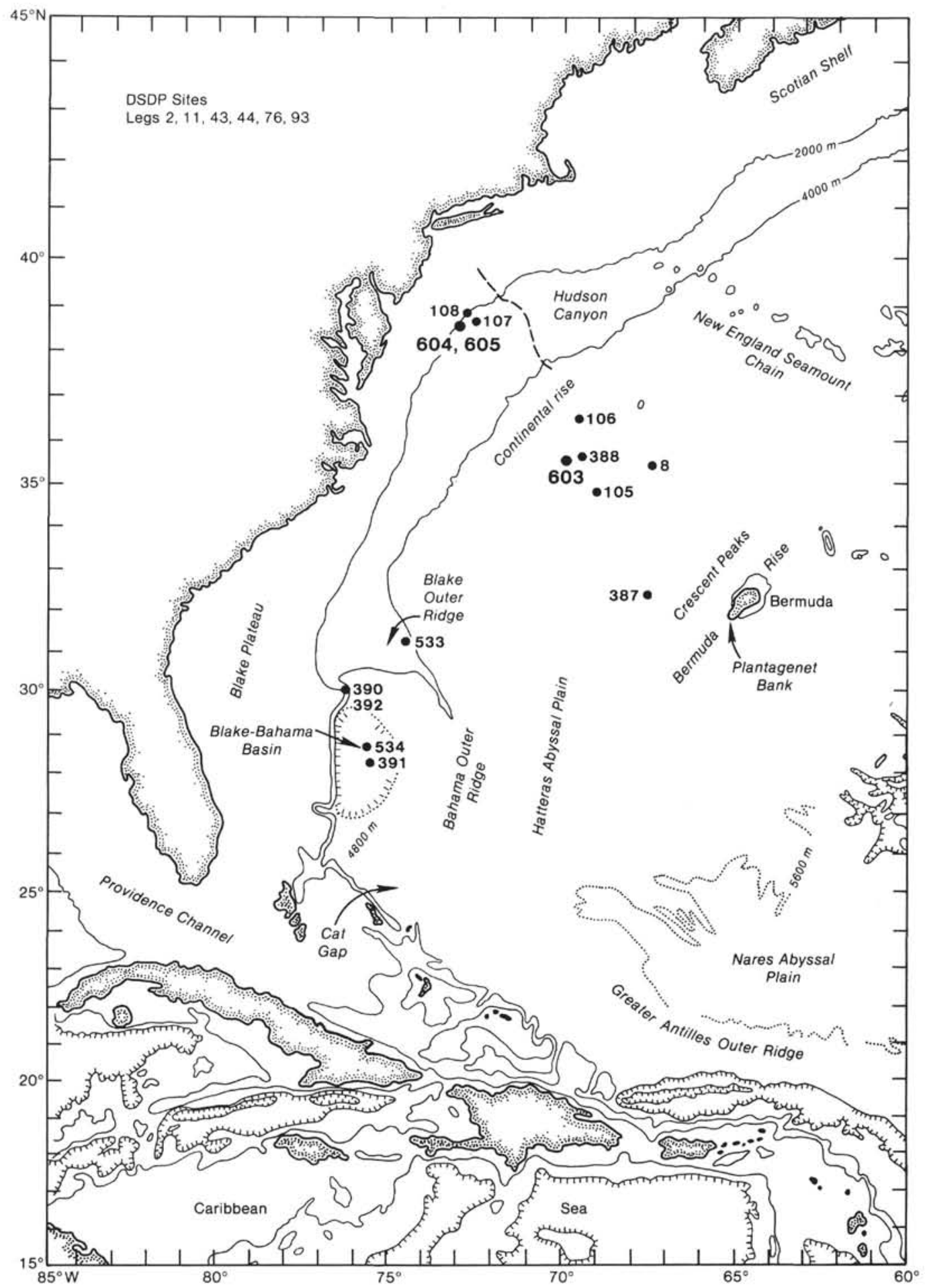

Figure 1. Location of DSDP Sites 604 and 605 on the New Jersey continental rise.

at Site 605 , which is apparently continuous with the Cretaceous section at this locality.

\section{METHODS, ZONATION, AND SPECIES CONSIDERED}

Smear slides from at least one sample per core section were prepared directly from the sediment, and the distributions of coccoliths and other nannoliths were recorded in the range charts for at least one sample per core except as noted in the text. A few samples are also dis- cussed in the text that, because of redundancy, are not recorded on the range charts. Abundances of coccoliths and other nannoliths were recorded using a format similar to that outlined by Hay (1970), except that the standard smear slides were examined at $1560 \times$ rather than at $1000 \times$. The format used is as follows:

$\mathrm{R}=\operatorname{rare}(1$ specimen in $101-1000$ fields of view at $1560 \times)$

$\mathrm{F}=$ few $(1$ specimen in $11-100$ fields of view at $1560 \times)$

$\mathrm{C}=$ common $(1$ specimen in $2-10$ fields of view at $1560 \times)$

$A=$ abundant $(1-10$ specimens per field of view at $1560 \times)$ 


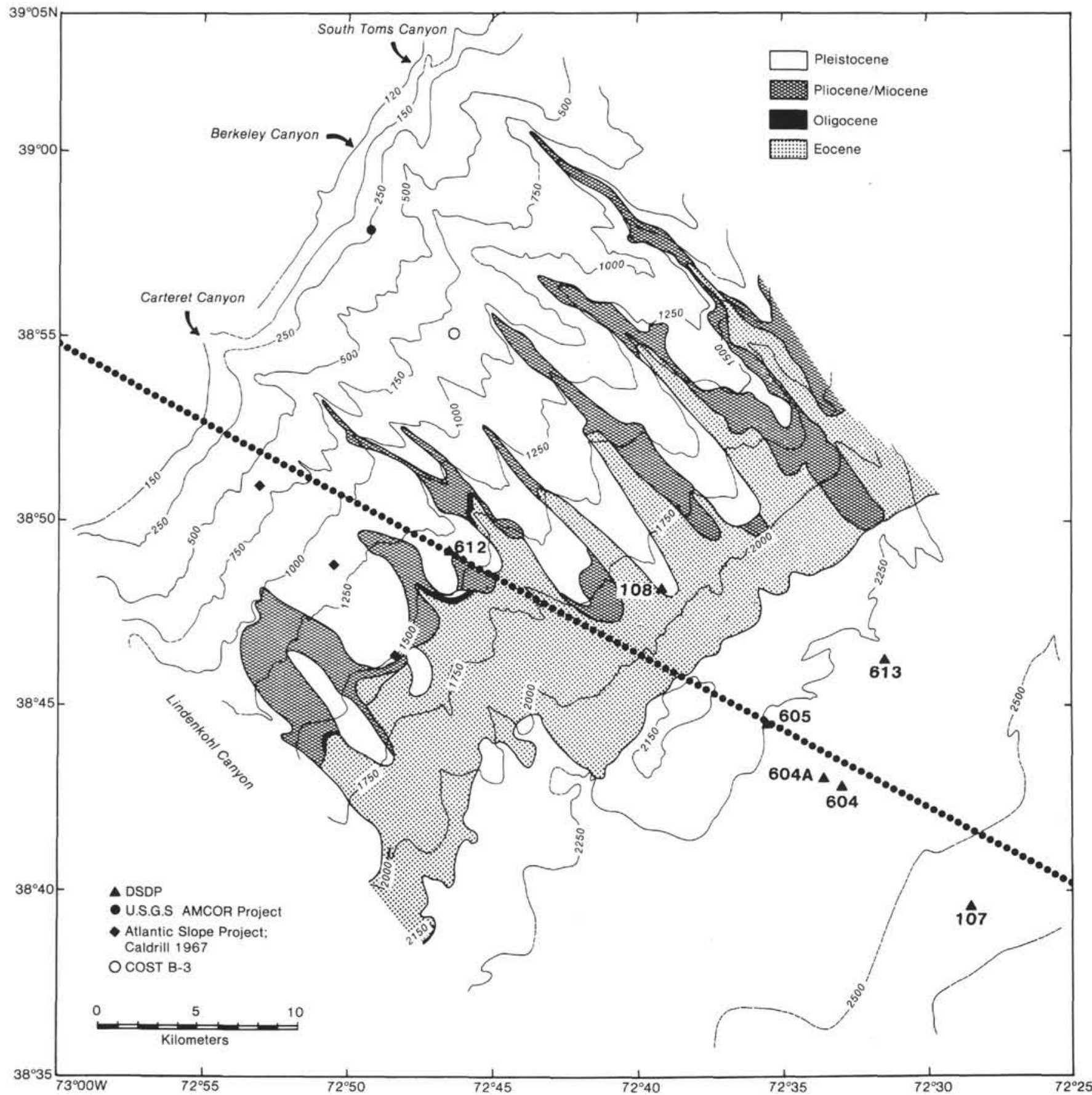

Figure 2. DSDP Sites 604 and 605 , other nearby drill sites, and multichannel seismic reflection profile U.S. Geologic Survey Line 25 superimposed on a geologic map of the New Jersey slope and rise. Geologic map after Robb et al. (1981, 1982). Note Eocene outcrop belt upslope from Site 604.

A qualitative description of the preservation of nannofossils is provided using a scheme modified from Lang and Watkins (1984):

$\mathrm{VG}=$ very good (no evidence of secondary alteration via etching and/or overgrowth)

$\mathrm{G}=$ good (little evidence of secondary alteration via etching and/ or overgrowth-identification of species not impaired)

$\mathrm{M}$ = moderate (significant evidence of secondary alteration via etching and/or overgrowth-identification of species not impaired)

$\mathrm{P}=$ poor (specimens typically heavily overgrown or severely etched-identification of some species significantly impaired).
The Mesozoic zonation applied in this study is from Cepek and Hay (1969). The Cenozoic zonation is that of Okada and Bukry (1980), except for the Pleistocene where the scheme of Gartner (1977) is used (Fig. 5). Because both zonal schemes base the Pliocene/Pleistocene boundary on the LAD of Discoaster brouweri, the combined scheme used in this chapter is continuous. One should note that Okada and Bukry's CN12d has recently been renamed the D. triradiatus Subzone (Bukry, 1985, p. 572), which avoids confusion when the two systems are combined. We have changed the name of the $D$. pentaradiatus Subzone $(\mathrm{CN} 12 \mathrm{c})$ to the D. misconceptus Subzone in order to conform with the nomenclatural changes proposed by Theodoridis (1984). In addition, because we do not distinguish between Sphenolithus abies 


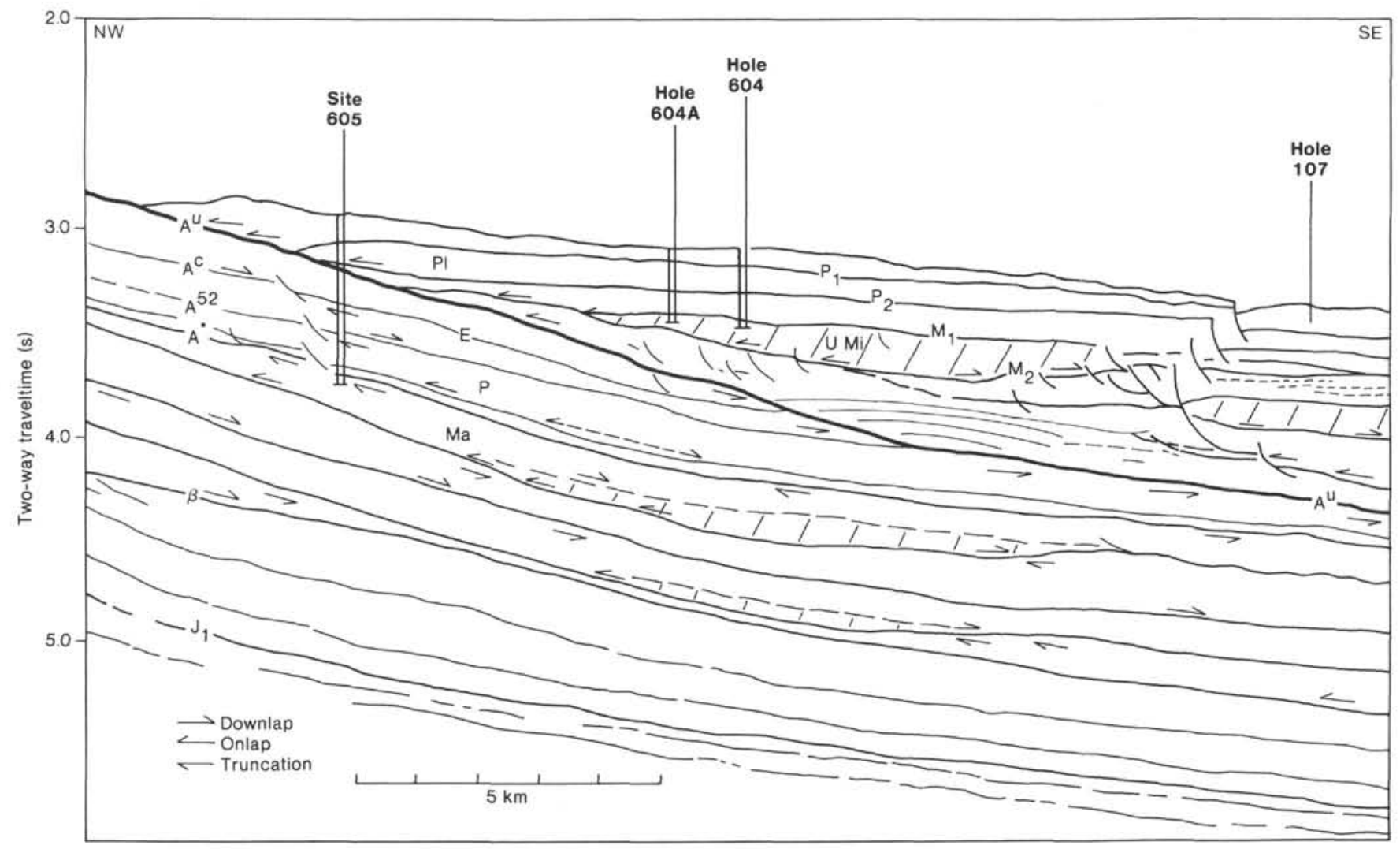

Figure 3. Line drawing after multichannel seismic reflection profile U.S. Geological Survey Line 25. Leg 93 holes and nearby DSDP Site 107 and shown. $\mathrm{PL}=$ Pliocene/Pleistocene, $\mathrm{U}$ Mi $=$ upper Miocene, $\mathrm{E}=$ Eocene, $\mathrm{P}=$ Paleocene, $\mathrm{Ma}=$ Maestrichtian. Reflection horizons (sequence boundaries) indicated to the left and right (from Wise et al., 1986, fig. 10).

and $S$. neoabies, we use the extinction of $S$. spp. as a codatum for the base of Zone CN12.

Taxa considered in this report are listed in Appendixes A and B where they are arranged alphabetically by generic epithets. Citations for these species are provided in the "Annotated index and bibliography of the calcareous nannoplankton, I-VII" (Loeblich and Tappan, 1966-1973) and from the "Bibliography and taxa of calcareous nannoplankton" (van Heck, 1979a, b-1983; Steinmetz, 1984a, b-1985).

\section{HOLE SUMMARIES}

\section{Hole 604 (Table 1)}

The 31 continuous cores in Hole $604\left(38^{\circ} 42.79^{\prime} \mathrm{N}\right.$; $72^{\circ} 32.95^{\prime} \mathrm{W}$; water depth, $2364 \mathrm{~m}$ ) penetrated the following lithostratigraphic units (Fig. 4).

Unit I: $84 \mathrm{~m}$ of Holocene(?) to Pleistocene gray to dark greenish gray clay and silt in alternating sequences. This unit contains reworked Eocene and Neogene microfossils and has some slumped or redeposited Eocene biosiliceous chalk in the upper $35 \mathrm{~m}$.

Unit II: $155 \mathrm{~m}$ of lower Pleistocene to upper Miocene greenish gray clay with variable amounts of glauconitic shelf sand turbidites and biogenic silica.

Unit III: $56 \mathrm{~m}$ of upper Miocene glauconitic, biosiliceous silty claystone, sand, and conglomerate. The conglomerates contain rounded quartz pebbles up to $1 \mathrm{~cm}$ long, clasts of claystone, chalk, and limestone up to 10 $\mathrm{cm}$ in diameter, and rare shell fragments. Elsewhere in the unit, exotic blocks of Eocene nannofossil chalk up to $50 \mathrm{~cm}$ thick are present. These and the conglomerates represent debris flows, whereas some of the sands could be turbiditic.

Coccoliths are generally few to rare in the first ten cores of Hole 604, which are late Quaternary in age (Emiliania huxleyi/Gephyrocapsa oceanica Zones). Characteristic forms are Calcidiscus leptoporus, Ceratolithus cristatus, G. caribbeanica, G. oceanica, Syracosphaera pulchra, and Umbilicosphaera sibogae.

Samples 604-1-1, 110-112 cm and 604-1-1, $130 \mathrm{~cm}$ contain a diverse, reworked Eocene assemblage that includes Campylosphaera dela, Chiasmolithus grandis, Coccolithus formosus, Discoaster barbadiensis, Isthmolithus recurvus, Neococcolithes dubius, Pontosphaera pulcher, Reticulofenestra umbilica, $R$. reticulata, and Rhabdosphaera tenuis. Samples 604-5-2, 50-54 cm and 604-5-2, $110-112 \mathrm{~cm}$ also contain reworked or redeposited Eocene sediments that contain forms similar to those mentioned above from Core 1.

The Pseudoemiliania lacunosa Zone, delimited by the last appearance datum (LAD) of the nominative species and combined with the small Gephyrocapsa Zone, is confined to Cores 604-11 and - 12 where coccolith abundance increases and preservation improves dramatically. This abrupt change plus the relatively short interval spanned by this zone may indicate a hiatus between Cores $604-10$ 


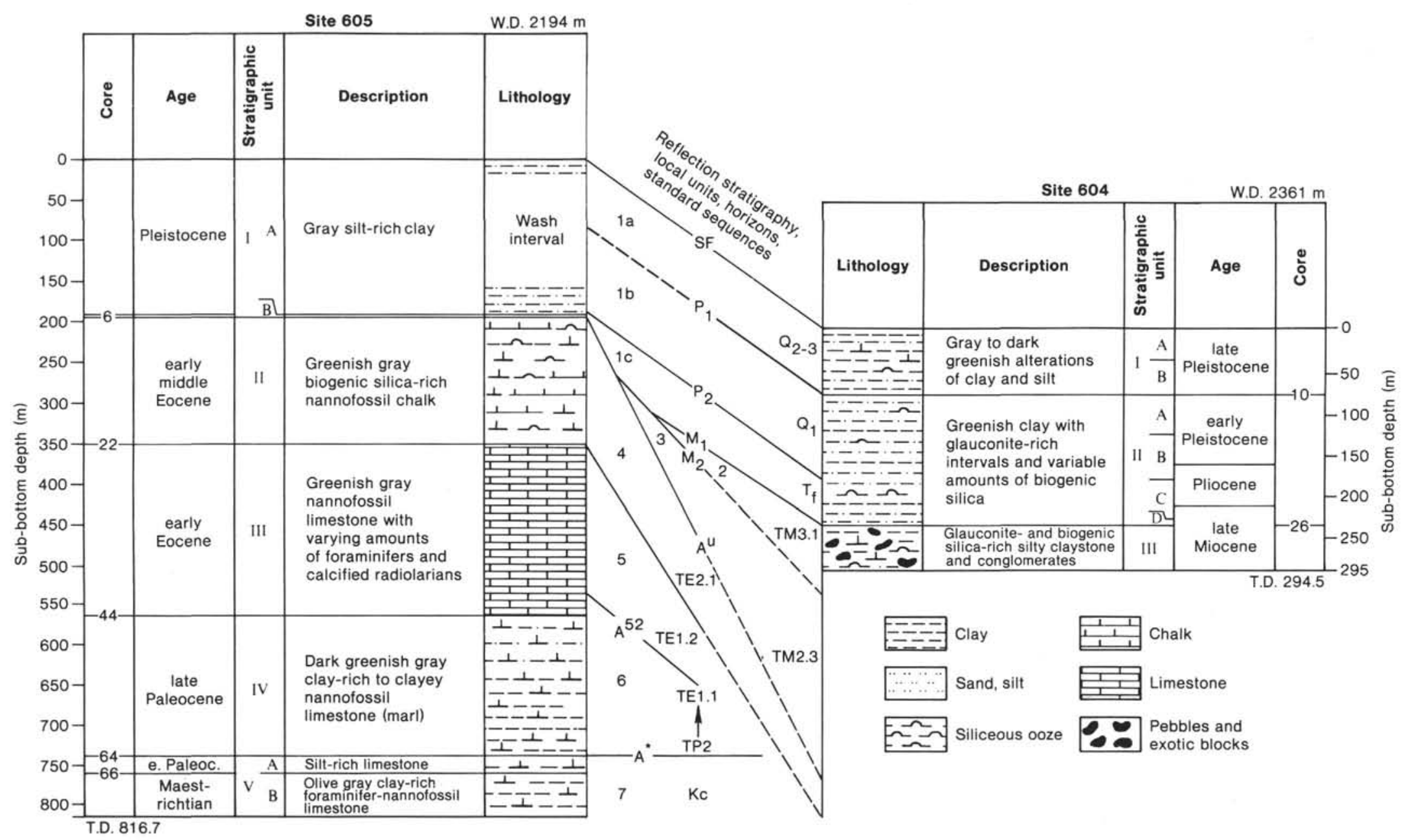

Figure 4. Stratigraphic summary of Sites 604 and 605 (Holes 604, 604A, and 605). Units I-III and I-V are local lithostratigraphic units. Standard seismic sequence notation after Vail et al. (1980) (from Wise et al., 1986, fig. 11). 


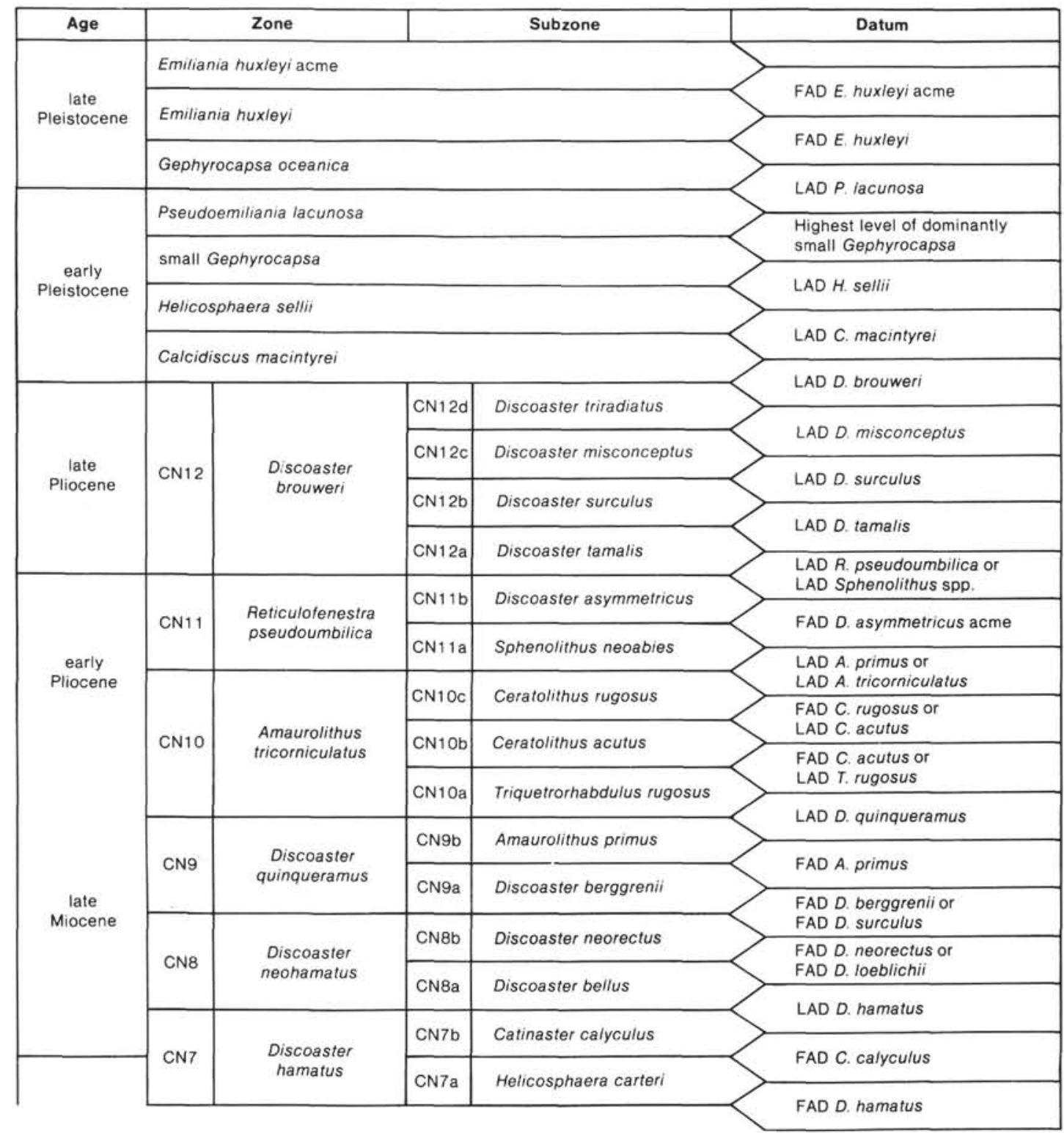

Figure 5. Nannofossil zonation scheme used in this chapter (from Gartner, 1977; Okada and Bukry, 1980; and Čepek and Hay, 1969).

and 605-11. The remainder of the Pleistocene is subdivided into the Helicosphaera sellii and Calcidiscus macintyrei Zones.

The Pleistocene/Pliocene boundary in Hole 604 is placed between Samples 604-18-2, 50-54 cm and 604$18-3,30-32 \mathrm{~cm}$ in that samples in and below $604-18-3$, $30-32 \mathrm{~cm}$ contain appreciable numbers of discoaster species commonly assigned to Pliocene or older assemblages. Samples from Section 604-18-3 down to Sample 604-19-5, $50-54 \mathrm{~cm}$ are assigned to the $D$. brouweri Zone. The common occurrence of discoasters as well as a number of background species allows a further but still incomplete division of this interval into the subzones described below.

Samples 604-18-3, 30-32 cm and 604-18-3, 110-112 $\mathrm{cm}$ are assigned to the $D$. triradiatus Subzone (CN12d). Species present in this interval include common $C$. macintyrei, Coccolithus pelagicus, $P$. lacunosa, and Syraco- sphaera pulchra, as well as few Discoaster brouweri, $H$. carteri, $H$. sellii, and Umbilicosphaera sibogae. Rare species in this interval include Ceratolithus cristatus, Pontosphaera japonica, and Rhabdosphaera clavigera.

Samples 604-18-4, 30-32 cm through 604-19-2, 50$54 \mathrm{~cm}$ are placed within the $D$. misconceptus Subzone (CN12c). Nannofossils present are similar to those in the overlying subzone except for the general increase in older Pliocene forms. Samples assigned to this interval contain abundant Crenalithus doronicoides, P. lacunosa, S. pulchra, and common Calcidiscus leptoporus, and Pontosphaera sp. aff. P. multipora. Calcidiscus macintyrei, Coccolithus pelagicus, D. triradiatus, D. misconceptus, $H$. carteri, $H$. sellii, $P$. japonica, $R$. clavigera, and $U$. sibogae are few.

Samples assigned to the $D$. misconceptus Subzone overlie two highly glauconitic samples $(604-19-3,30-32 \mathrm{~cm}$ and 604-19-3, 50-54 cm) barren of nannofossils. The $D$. 


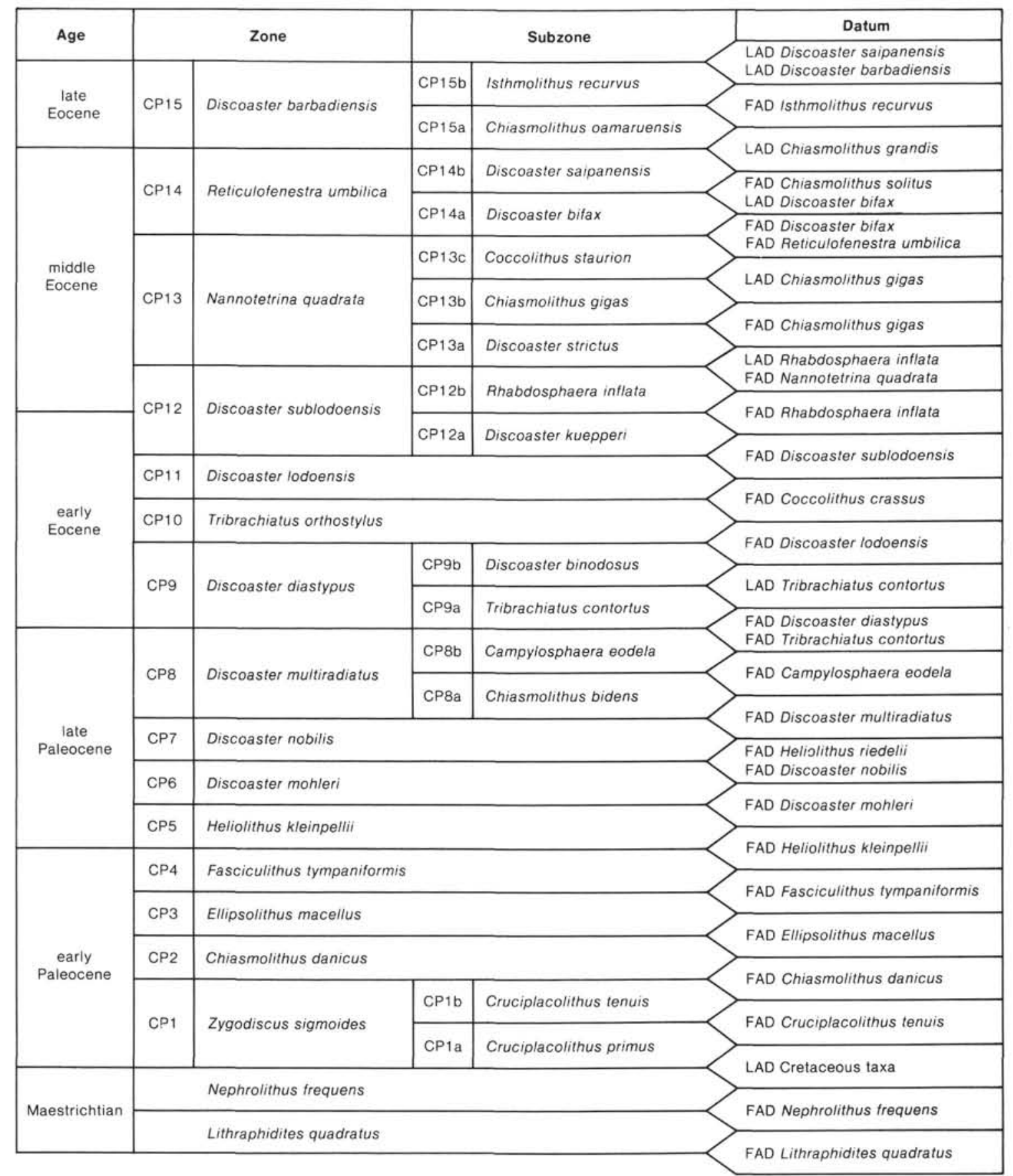

Figure 5 (continued).

surculus Subzone (CN12b) cannot be documented in this sequence, and we suspect a disconformity in the vicinity of the barren interval, which, at best, must be considered a condensed interval (see section below on "Sedimentation Rates, Hiatuses, and Correlation with Seismic Reflection Horizons").

The barren samples discussed above are underlain by a series of samples, 604-19-4, 30-32 cm through 604-19-5, 50-54 cm, assigned to the $D$. tamalis Subzone (CN12a). They contain assemblages similar to those in overlying samples plus rare $D$. tamalis and abundant $D$. triradia- tus. Nannofossil abundance increases dramatically in samples below the barren interval.

Samples from the $604-20-1,50-54 \mathrm{~cm}$ to $604-21-4$, 30-32 cm interval are assigned to the Reticulofenestra pseudoumbilica Zone (CN11). Subdivision of this interval into subzones is difficult because of a low abundance of D. asymmetricus and diminished preservation, which inhibits the distinction among forms similar to the delicate-rimmed $P$. lacunosa. Species within this interval include abundant Calcidiscus leptoporus, Coccolithus pelagicus, and Crenalithus doronicoides, and common Cal- 
Table 1. Distribution of Neogene and redeposited Eocene calcareous nannofossils, Site 604.

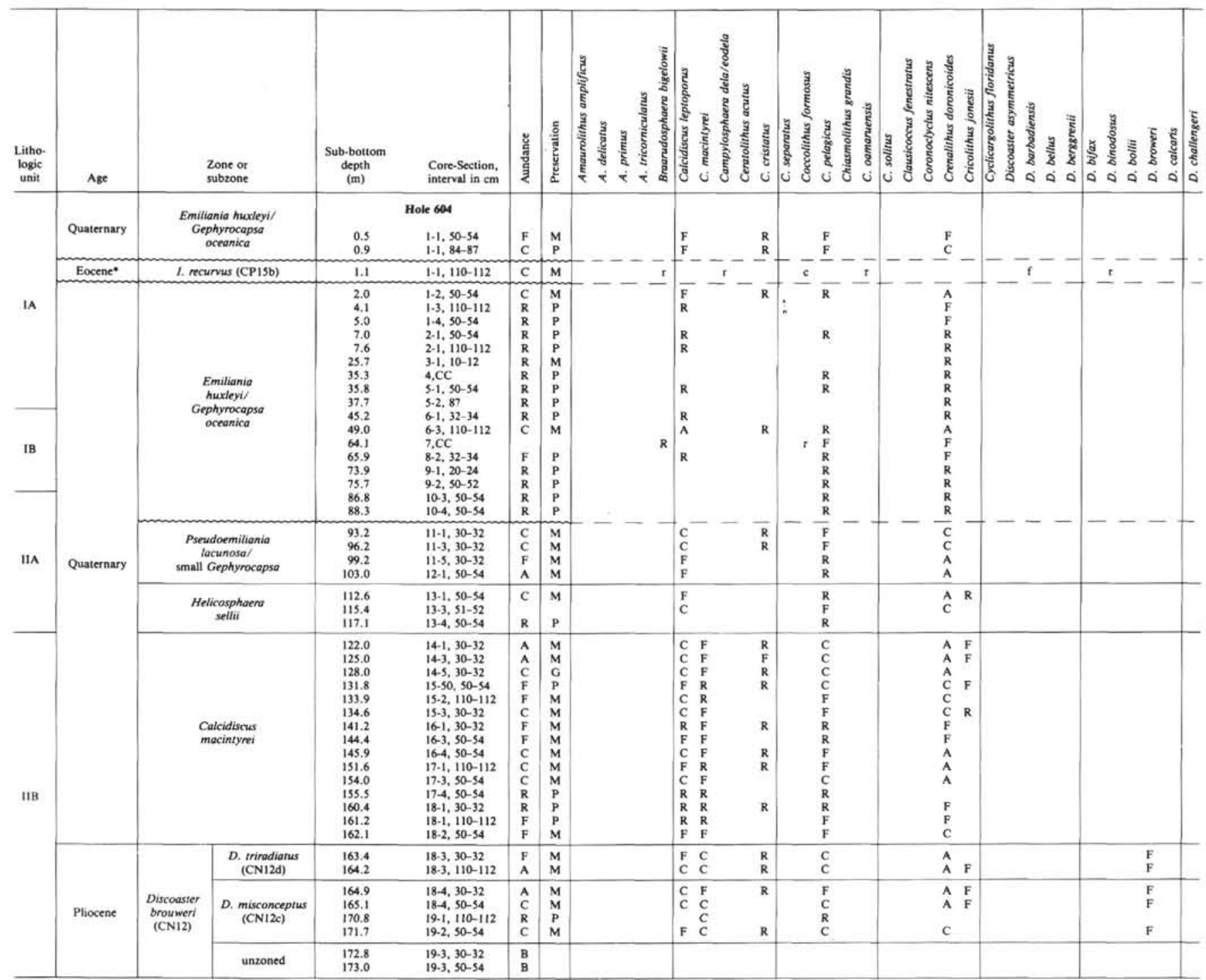

Note: Abundance is characterized by V, very abundant; $A$, abundant; $C$, common; $F$, few; $R$, rare. For preservation, $P$, poor; $M$, moderate; $G$, good. Lower-case letters indicate material considered to be reworked upsection or caved downhole. See "Methods" section in text for further explanation." = redeposited.

cidiscus macintyrei, D. brouweri, $H$. carteri, Pontosphaera japonica, Pseudoemiliania lacunosa, and $U$. cricota. Where present, $D$. asymmetricus is rare. Utilization of the first appearance datum of $P$. lacunosa (Bergen, 1984) was not possible because of poor preservation.

The highest stratigraphic occurrence of amauroliths occurs in Sample 604-22-1, 110-112 cm. The interval from this sample to Sample 604-24,CC is assigned to the Amaurolithus tricorniculatus Zone (CN10). Species within this interval include those seen in younger samples plus $A$. delicatus, $A$. primus, and $A$. tricorniculatus. This interval is also marked by an increased abundance of $S c y$ phosphaera lopadoliths. Sample 604-22-1, 110-112 cm contains especially diverse lopadoliths. Observed species include $S$. globulata, $S$. pulcherrima, and $S$. recurvata.

The Pliocene/Miocene boundary is placed at the top of Core 604-25, based on the LAD of D. quinqueramus. $D$. berggrenii is common at that level, and very little sediment was recovered in Core 24 , thus it is probable that a complete boundary sequence was not captured at this site. Criteria for placing the "nannofossil Miocene/ Pliocene boundary" are discussed at length by Muza, Wise, and Covington (this volume).

Section 604-25-1 contains D. quinqueramus and $D$. berggrenii and is assigned to the $D$. quinqueramus Zone (CN9). It is followed by a relatively long interval (604$25-1,110-112 \mathrm{~cm}$ to $604-26-2,110^{\circ} 112 \mathrm{~cm}$ ) within which samples either lack nannoliths or contain rare, poorly preserved non-age-diagnostic species. Siliceous microfossils are present (McCartney and Wise, this volume).

Sample 604-26-2, $120 \mathrm{~cm}$ is from lithostratigraphic Unit III, which contains a number of spectacular debris flows (Fig. 6). This sample is from chalky sediment containing a late Eocene assemblage. Species present are representative of the Isthmolithus recurvus (CP15b) Subzone and include abundant Coccolithus formosa, C. pelagicus, Cyclicargolithus floridanus, D. saipanensis, I. recurvus, and common $D$. barbadiensis, Pontosphaera 
Table 1 (continued).

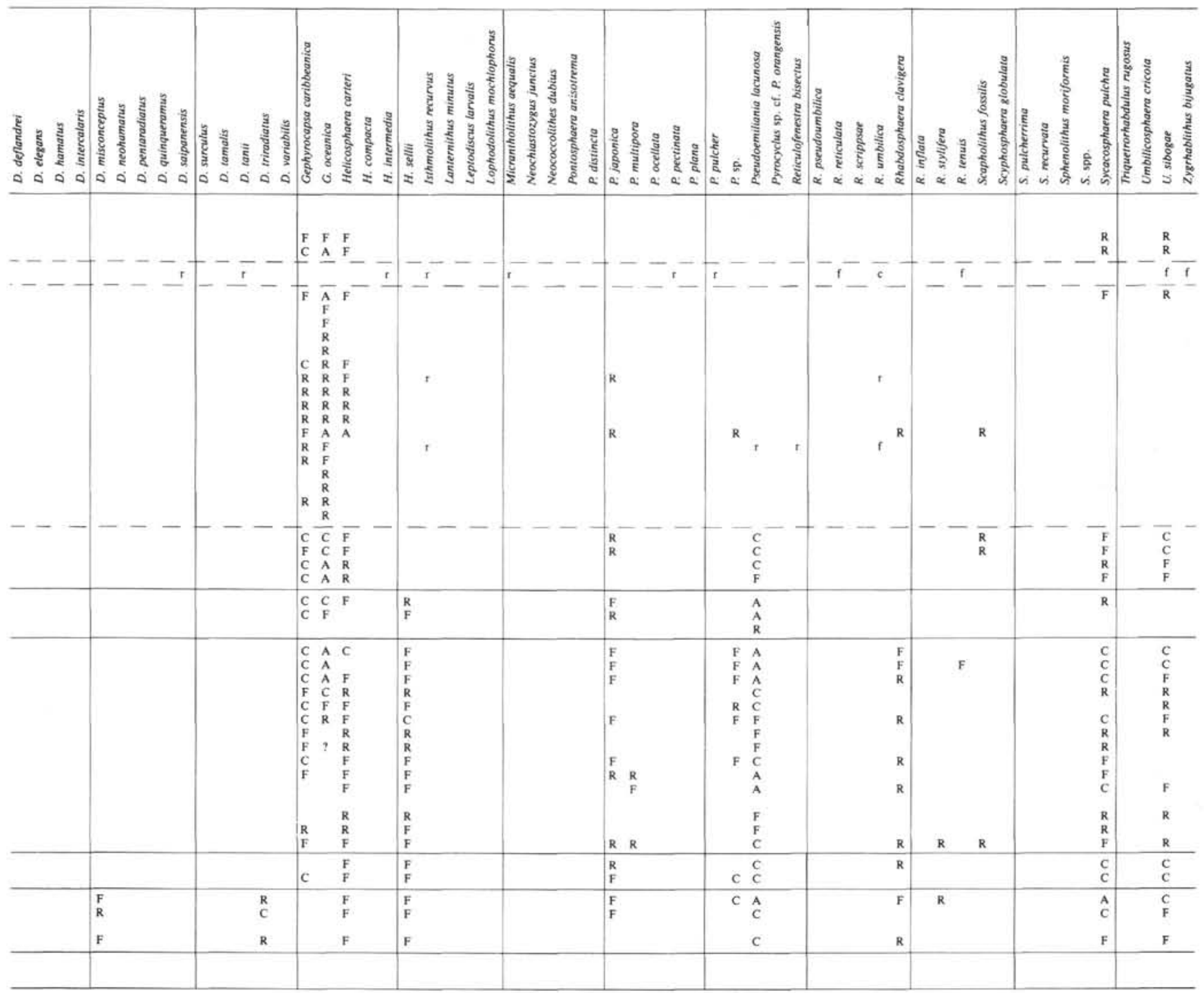

pectinata, $R$. bisecta, $R$. reticulata, Rhabdosphaera tenuis, and Zygrhablithus bijugatus.

This sample is immediately underlain by an in situ upper Miocene assemblage (Sample 604-26-2, $145 \mathrm{~cm}$; see Fig. 6) that includes $D$. asymmetricus, $D$. bollii, $D$. brouweri, D. calcaris, D. intercalaris, D. neohamatus, $D$. pentaradiatus, and $D$. variabilis. Other forms present include Calcidiscus macintyrei, $H$. carteri, Pyrocyclus orangensis, and Reticulofenestra pseudoumbilica. Taking into account the presence of $D$. bollii, this assemblage can be assigned to the $D$. bellus Subzone (CN8a) of the D. neohamatus Zone (see Perch-Nielsen, 1985, fig. 7). Downhole, in Sample 604-26-3, $18 \mathrm{~cm}$, another Eocene assemblage is encountered. Like the one from $604-26-2,120 \mathrm{~cm}$, this sample is assigned to the $I$. recurvus Subzone ( $\mathrm{CN} 15 \mathrm{~b})$. The underlying samples down to $604-27-1,29-30 \mathrm{~cm}$ are assigned to the $D$. bellus Subzone (CN8a).

Continuing through the debris flows, Samples 604$27-1,50-54 \mathrm{~cm}$ and $604-27-1,80 \mathrm{~cm}$ contain a middle Eocene assemblage assignable to the Discoaster bifax Sub- zone (CP14a). Species present include common Chiasmolithus solitus, Coccolithus formosus, Pontosphaera pulcher, and Zygrhablithus bijugatus as well as few Clausicoccus fenestratus, $D$. saipanensis, $D$. barbadiensis, $H$. intermedia, Reticulofenestra umbilica, and Rhabdosphaera tenuis. This suite of samples represents an emplaced Eocene block somewhat older than the one occurring directly uphole.

Samples 604-27-1, $113 \mathrm{~cm}$ and 604-27-1, 138-139 cm are barren of nannoliths, but are underlain by an interval beginning with Section 604-28-1 (the only section recovered in that core) assigned to the upper Miocene $D$. hamatus Zone (CN7). This is the oldest dated sediment in the hole that we consider to be in situ. Species present within this interval include Calcidiscus macintyrei, Catinaster calyculus, Coccolithus pelagicus, D. challengeri, D. hamatus, D. variabilis, $H$. carteri, and Reticulofenestra pseudoumbilica.

No sediment was recovered in Core 604-29. Sample 604-30-1, 79-80 cm contains discoasters and sparsely scattered placoliths that in themselves, are not age-diagnos- 
Table 1 (continued).

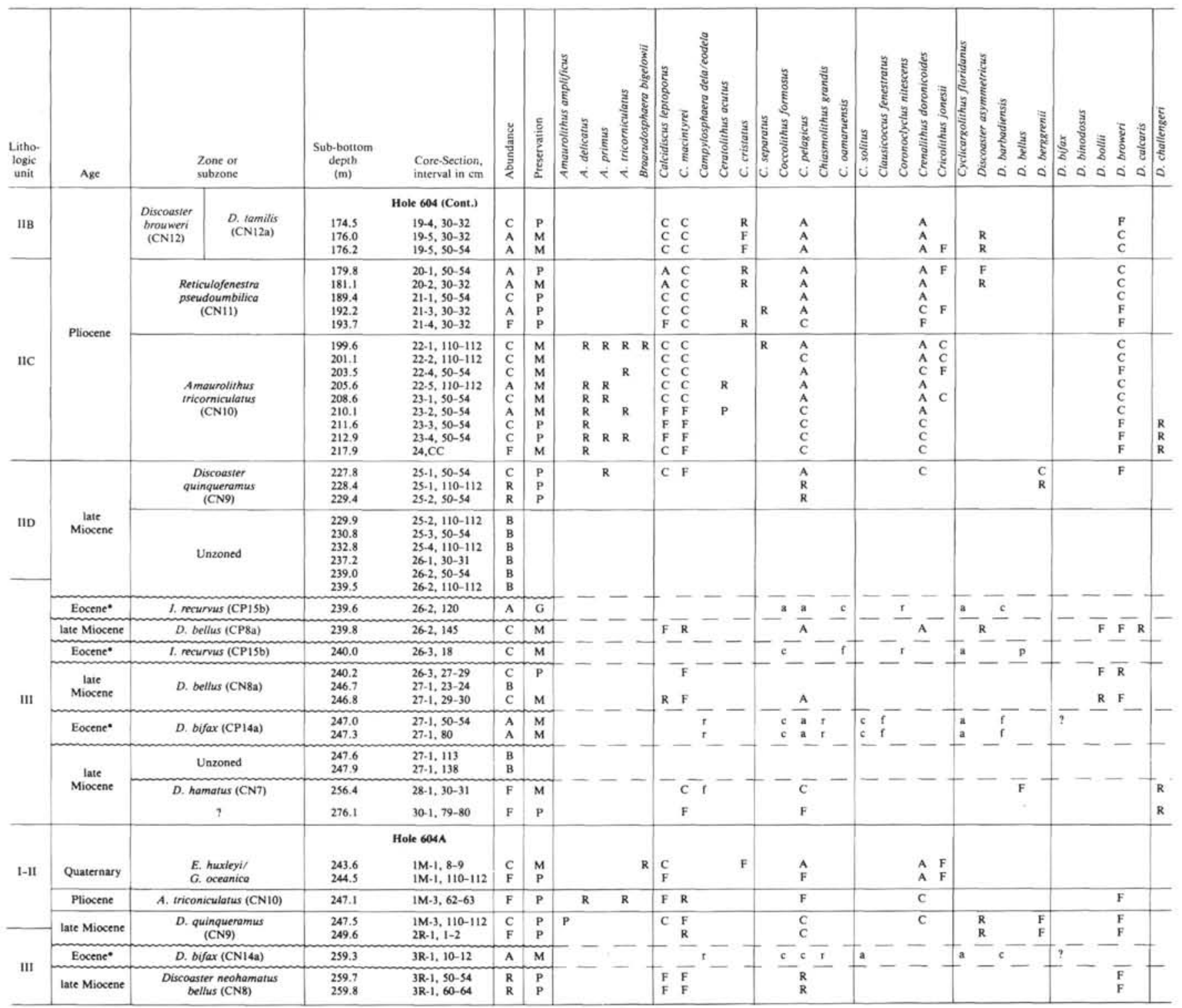

tic. No sediment was recovered in Core 604-31, which was cut with great difficulty due to the caving of "suitcase sands" that made for highly unstable hole conditions. Consequently, Hole 604 was terminated at $294.5 \mathrm{~m}$ sub-bottom depth.

\section{Hole 604A (Table 1)}

Three partially filled cores represent the total sedimentary recovery made at Hole $604 \mathrm{~A}\left(38^{\circ} 43.08^{\prime} \mathrm{N}\right.$; $72^{\circ} 33.64^{\prime} \mathrm{W}$; water depth, $2340.00 \mathrm{~m}$ ). The first core was washed down $249.8 \mathrm{~m}$, collecting sediment along the way until full. This "wash" core is designated in Table 1 by the letter "M" (for "miscellaneous"). It contains an upper sediment unit that in Section 604A-1M extends downcore to at least $112 \mathrm{~cm}$, and yielded nannofossil populations characteristic of the Pleistocene.

Three sections down, Sample 604A-1M-3, 62-64 cm contains nannoliths indicating an age of earliest Pliocene to latest Miocene (Amaurolithus tricorniculatus Zone, CN10). Sample 604-1M-3, 110-112 cm and rotary ("R") core Sample 604-2R-1, 1-2 cm contain nannoflora indicative of the Discoaster quinqueramus Zone (CN9). Species present include common Calcidiscus leptoporus, Coccolithus pelagicus, Crenalithus doronicoides, D. quinqueramus, $R$. pseudoumbilica, and few $D$. berggrenii, D. surculus, D. variabilis, Helicosphaera carteri, Triquetrorhabdulus rugosus, and Umbilicosphaera cricota. The former sample is distinguished by well-preserved $T$. rugosus.

A clast near the top of rotary core Section 604A-3R-1 at $10-12 \mathrm{~cm}$ yielded another middle Eocene assemblage assigned to CP14a with a species composition similar to that reported for Samples 604-27-1, 50-54 cm and -80 $\mathrm{cm}$ from the first hole at this site. The remaining sediments in Core 604A were confined to the first section. These are considered to be in situ with an upper Mio- 
Table 1 (continued).

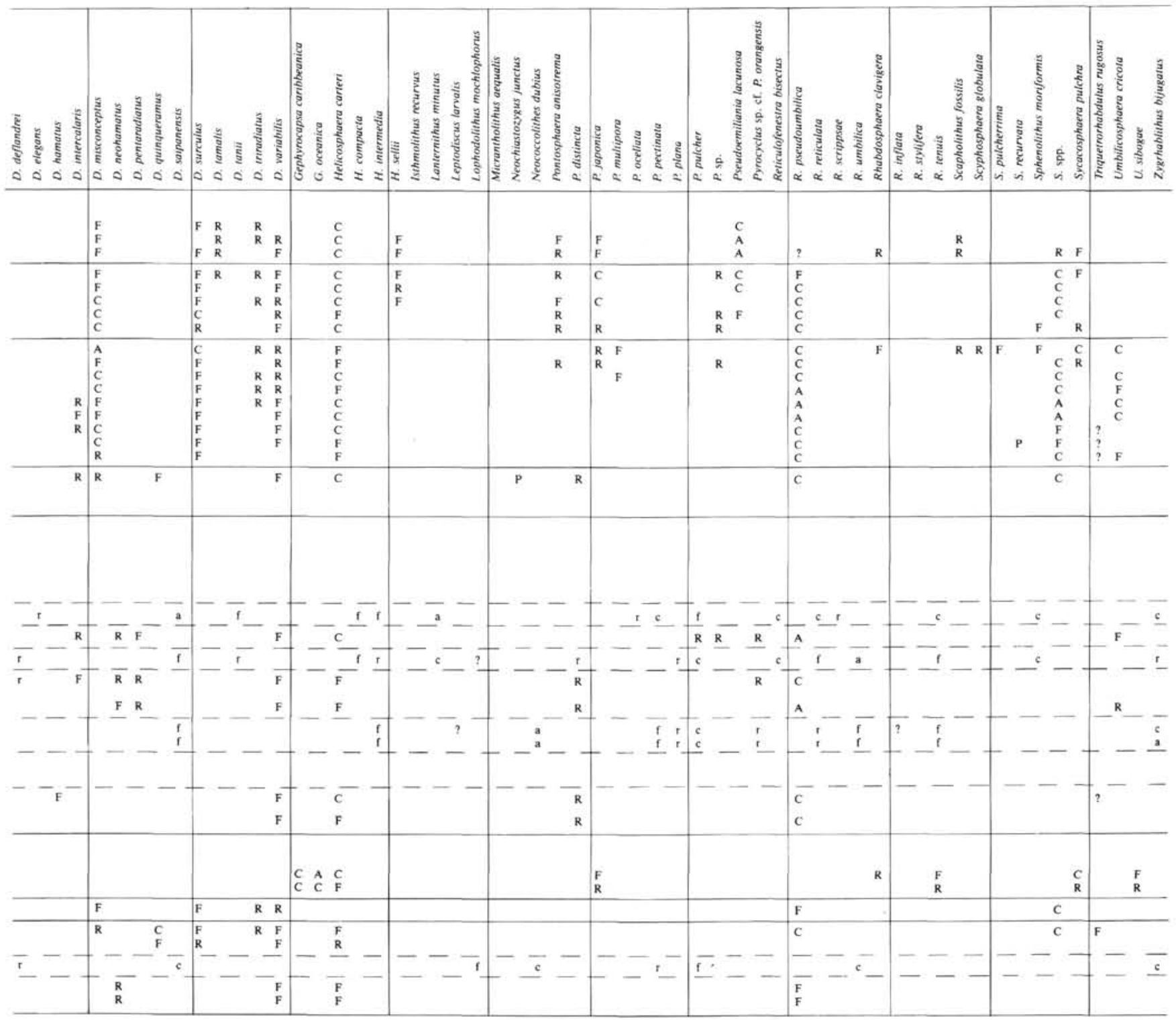

cene coccolith assemblage from the $D$. bellus Subzone (CN8a) of the D. hamatus Zone equivalent to that in Cores 604-26 and 604-27.

\section{Hole 605 (Tables 2A and 2B)}

Seventy-one cores cut in Hole $605\left(38^{\circ} 44.53^{\prime} \mathrm{N} ; 72^{\circ}\right.$ $36.55^{\prime} \mathrm{W}$; water depth, $2197.00 \mathrm{~m}$ ) sampled the following lithostratigraphic units (Fig. 4):

Unit I: $198 \mathrm{~m}$ of Pleistocene gray silt-rich clay.

Unit II: $153 \mathrm{~m}$ of lower middle Eocene biosiliceous nannofossil chalk rich in siliceous microfossils.

Unit III: $214 \mathrm{~m}$ of lower Eocene greenish gray nannofossil limestone.

Unit IV: $176 \mathrm{~m}$ of upper Paleocene dark greenish gray clayey nannofossil limestone (marl).

Unit V: $77 \mathrm{~m}$ of lower Paleocene to upper Maestrichtian olive gray clayey limestone.
All of the Maestrichtian-Eocene units are strongly bioturbated. Coccoliths are generally common to abundant in the Paleocene, where preservation is characteristically moderate, but better than that in the overlying Eocene. Abundances are high in the Maestrichtian where preservation is generally good to moderate, but there are some poorly preserved intervals toward the bottom of the hole.

Only six cores were taken in the Pleistocene section, which is far better represented in Hole 604, therefore Cores 605-1 to 605-6 are not described here. As stated previously, the Eocene nannofossils from this hole are described by Applegate and Wise (this volume). The Paleocene-Maestrichtian coccolith assemblages, beginning with those in Section 605-44-2, are described below.

The upper Paleocene Discoaster multiradiatus Zone (CP8) spans the interval from $605-44-2,50-52 \mathrm{~cm}$ to $605-$ 


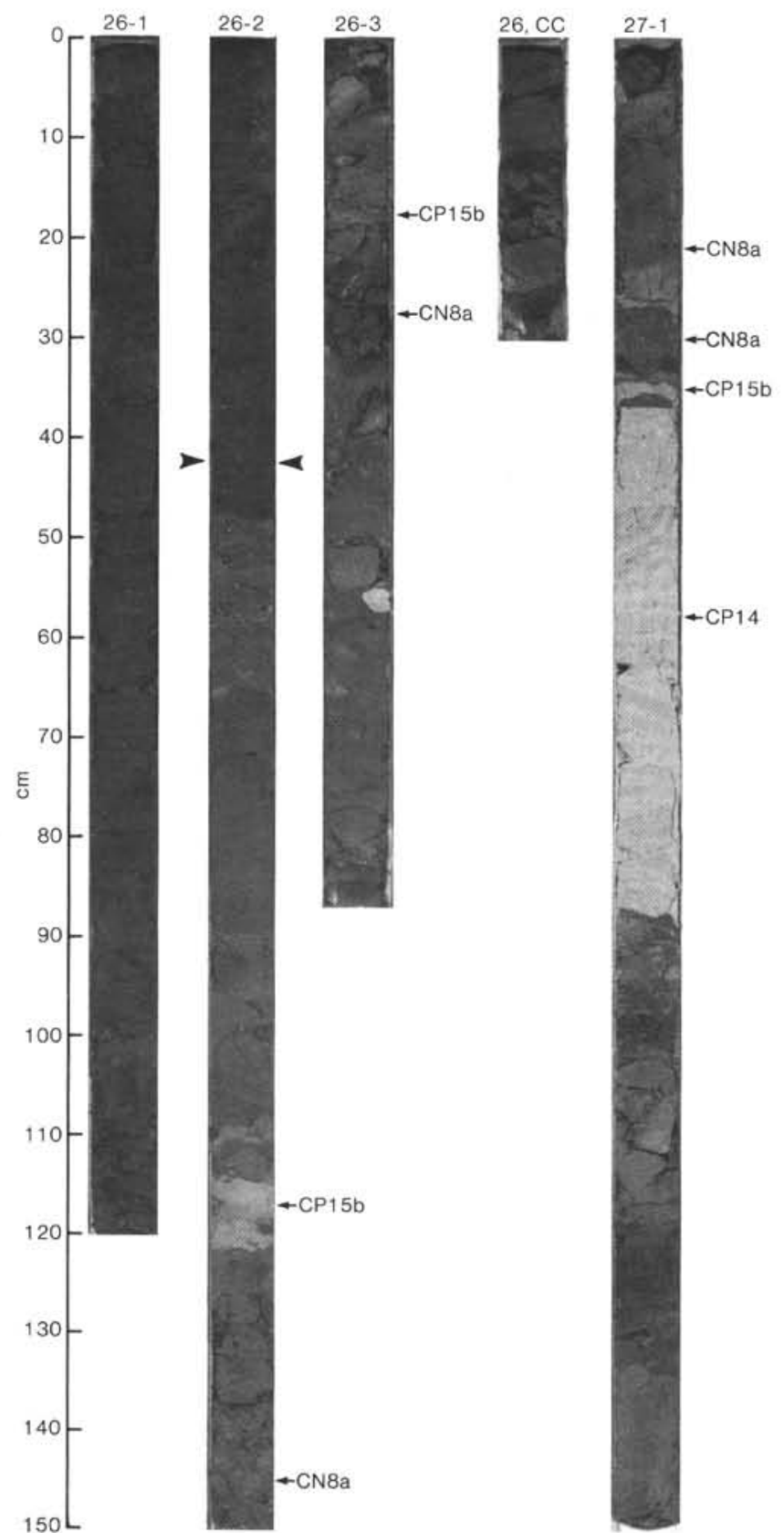

Figure 6. Cores 604-26 and -27 from upper Miocene Unit III of Hole 604 . Top of the youngest debris flow is indicated by arrowheads at 604-26-2, $46 \mathrm{~cm}$. Calcareous nannofossil assemblages from Zone $\mathrm{CN} 8$ are labeled along with redeposited Eocene chalk or ooze from Zones CP14 (middle Eocene) and CP15 (upper Eocene).

48-4, 110-112 (Table 2A). Species present include Campylosphaera eodela, Chiasmolithus bidens, C. consuetus, Coccolithus pelagicus, D. multiradiatus, D. nobilis, Toweius eminens, and species of Fasciculithus. This zone cannot be subdivided at this locality into Subzones CP8b and CP8a by the FAD of the Campylosphaera eodela, because this marker apparently ranges all the way to the base of the zone and beyond.

Samples from 605-48,CC through 605-49-2, 110-112 cm (not on Table 2) lack $D$. multiradiatus and are placed in the D. nobilis Zone (CP7). Save for the lack of $D$. multiradiatus and of Campylosphaera eodela below Sample $605-49-3,50-52 \mathrm{~cm}$, this assemblage is similar to that of the overlying interval.

The D. mohleri Zone (CP6) spans the interval from Sample $605-49-3,50-52 \mathrm{~cm}$ to Sample 605-50-5, 50-52 $\mathrm{cm}$. Absent are forms attributed to $F$. involutus and " $E r$ icsonia" robusta, which were present in the overlying zone. Observed for the first time in this hole are rare to common Heliolithus kleinpellii and rare $H$. sp., and common to abundant Prinsius bisulcus. Chiasmolithus consuetus and $C$. californicus are sparse but consistently present.

Below the FAD of $D$. mohleri, sediments of the $H$. kleinpellii Zone (CP5) are first encountered in Sample 605-50-5, 110-112 cm (not on Table 2). An assemblage characteristic of this zone persists down to Sample 605$56-2,50-52 \mathrm{~cm}$ and includes, in addition to those discussed previously, rare Cruciplacolithus tenuis in the lower part, and the first rare Neochiastozygus junctus in the upper part. In addition, rare to few $D$. bramlettei are consistently present in the uppermost samples from Section 605-52-3 to the top of the zone. At this locality, this taxon is an ideal marker for recognizing or subdividing the top of this zone.

The $F$. tympaniformis Zone (CP4) encompasses 605 $56-4,50-52 \mathrm{~cm}$ to $605-63-1,110-112 \mathrm{~cm}$. The nannofossil population is similar to that of the overlying zone except that $H$. kleinpellii is absent. The FAD of Sphenolithus primus is noted in the topmost sample, just below that of $H$. kleinpellii. The LAD of Chiasmolithus danicus is in Sample 605-57-2, 110-111 cm, and the first consistent occurrence of $T$. eminens s. ampl. is near the midpoint (Sample 605-60-6, 50-52 cm). The LAD of $\mathrm{Coc}$ colithus cavus is noted in 605-62-1, 110-112 cm, and the first rare Chiasmolithus consuetus are in the next sample down.

Below the FAD of $F$. tympaniformis, the nannofossil population that we assign to the Ellipsolithus macellus Zone (CP3) is little changed from that of the superjacent zone. This assignment is an interpretation because the zonal marker, Ellipsolithus macellus, is absent in this short (two-sample) interval in the lower part of Core 605-63 and occurs only sporadically in trace amounts in the Paleocene above. The base of the zone is marked instead by a disconformity between Cores 605-63 and -64, which truncates the ranges of several coccolith species above and below. This disconformity is a major discontinuity in the section that is visible lithologically (Fig. 7; arrow left, enlargement right), has been detected in the planktonic foraminiferal and paleomagnetic records for this hole (Smit and van Kempen; Canninga et al., this volume, respectively), and may correspond to the A* seismic discontinuity (Wise and van Hinte, this volume).

Species of the $E$. macellus Zone whose lower ranges are truncated by this disconformity include $C$. bidens and $T$. craticulus, both of which are common in Sample $605-63-5,50-52 \mathrm{~cm}$ immediately above the break. Because the FADs of $C$. bidens and $T$. craticulus occur within the E. macellus Zone (Romein, 1979; Okada and Buk- 
Table 2A. Distribution of Paleocene calcareous nannofossils, Site 605.

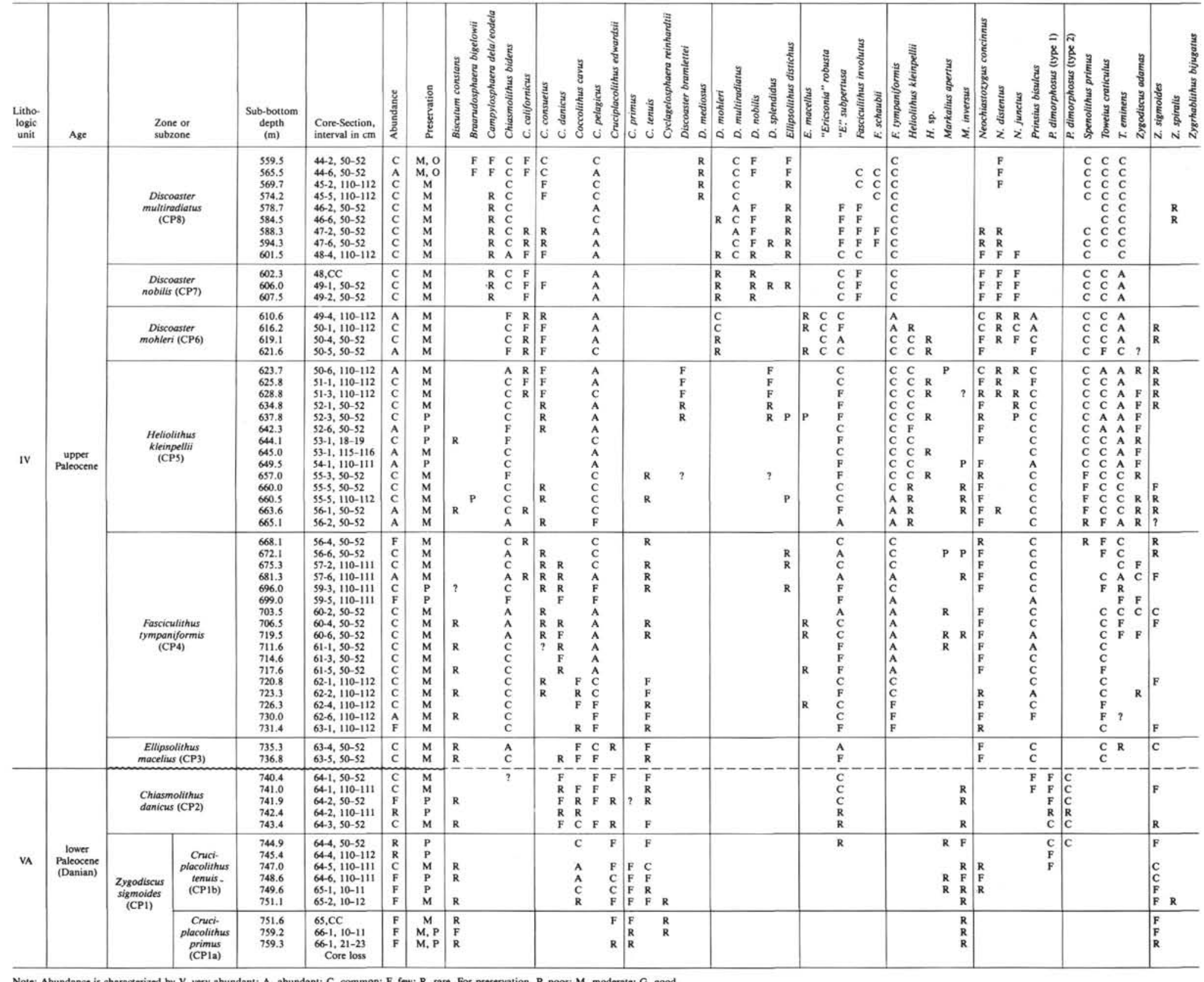



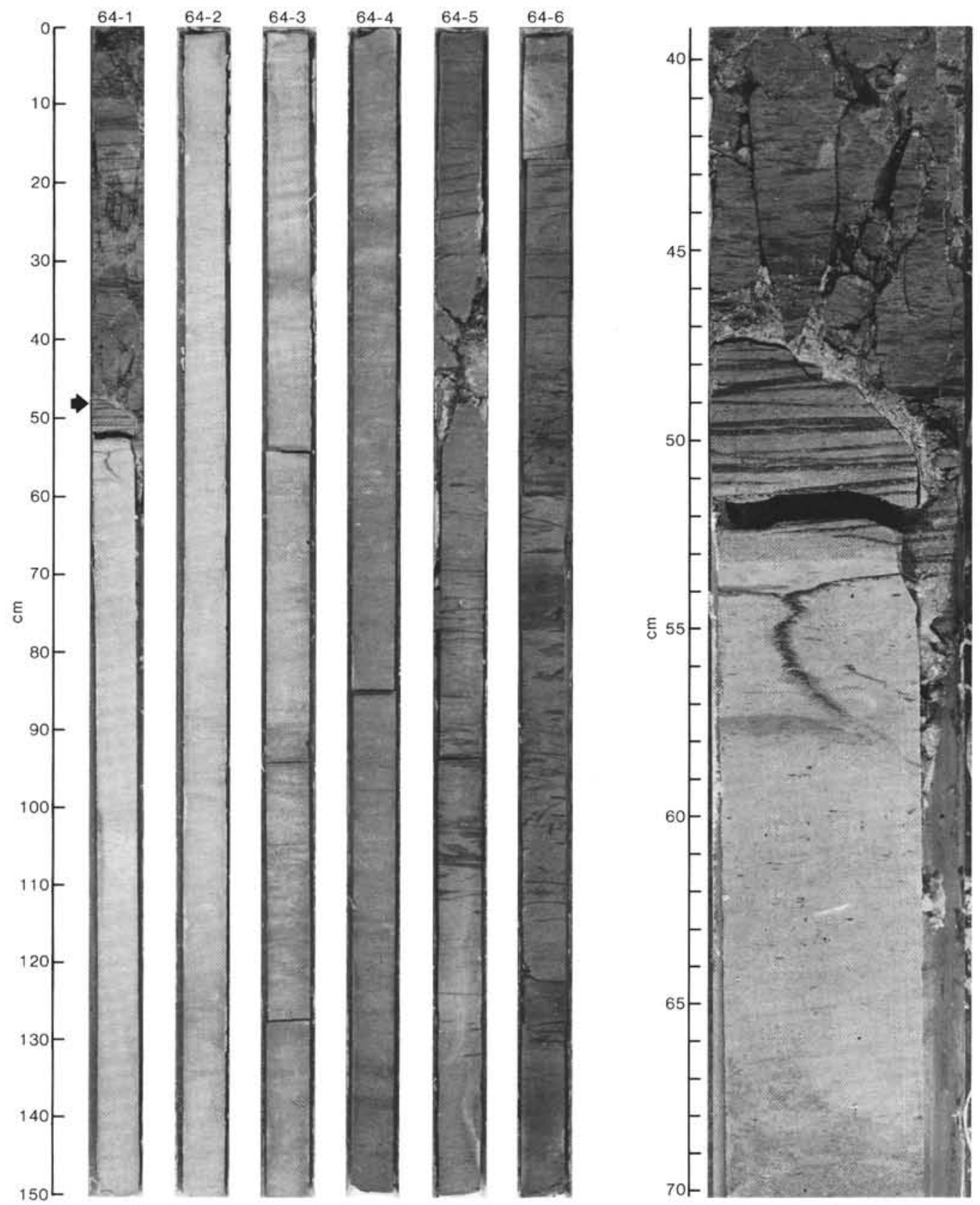

Figure 7. Paleocene Core 605-64 showing a lithologic break in Section 1 (arrow left, enlargement right) that marks a 2.6-m.y. hiatus separating Danian sediments below (lower nannofossil Zone CP2) from upper Paleocene sediments above (upper Zone CP3). This break also corresponds with the Vail Cycle TE2.1 lowstand and with seismic reflection Horizon $\mathrm{A}^{*}$ ? . The change in shade to a lighter color below the break corresponds to a change from a clayey limestone above to a rather pure foraminiferal limestone below. Note also change in bioturbation pattern on either side of the break.

ry, 1980, respectively), their simultaneous and abrupt appearance in this section is a strong indication that the base of the zone is not represented in this section.

Taxa of the Chiasmolithus danicus Zone (CP2) whose upper ranges are truncated by the hiatus in question are Prinsius dimorphosus (types 1 and 2). These are few to common immediately below the break and are consistently present throughout $\mathrm{CP} 2$. The stratigraphic consequence of the hiatus on this section, therefore, has been the deletion of the lower portion of Zone CP3 and the upper portion of Zone CP2.

Preservation deteriorates in the $C$. danicus Zone (CP2), particularly toward the base where coccoliths are scarce (Section 605-64-2). The abundance of coccoliths then declines progressively in the interval from Samples 605$64-5,110-111 \mathrm{~cm}$ to $605-66-1,21-23 \mathrm{~cm}$, which falls within the Zygodiscus sigmoides Zone (CP1). This zone marks the base of the Tertiary and contains the first coccoliths 
to have evolved following the extinctions at the end of the Cretaceous.

The CP1 assemblage is characterized by rare to abundant Coccolithus cavus and rare to common Cruciplacolithus tenuis that are present down to their FAD's at $605-65-2,10-12 \mathrm{~cm}$, and by rare to common C. edwardsii, which ranges to the base of the recovered Tertiary section where preservation improves somewhat. Also consistently present are rare to few Markalius inversus and Zygodiscus sigmoides, whereas rare Cyclagelosphaera reinhardtii occur near the base. The FAD's of "Ericsonia" subpertusa and Prinsius dimorphosus (types 1 and 2) are near the top of the zone. Sprinkled throughout CP1 are rare reworked Cretaceous species (see Table 2B) and a large number of thoracosphaerids.

In following the zonal scheme of Okada and Bukry (1980), we subdivide the Zygodiscus sigmoides Zone into Subzones CP1b and CP1a based on the FAD of $\mathrm{Cru}$ ciplacolithus tenuis in Section 605-65-2. The succession of datums here is also similar to the sequence suggested by Romein (1979, fig. 27) except that we record the FAD of $C$. tenuis below that of $P$. dimorphosus, a disparity that may be attributed to a slight difference in the taxonomic concept of $C$. tenuis.

The co-occurrence of $C$. edwardsii and $C$. primus down to the base of the recovered Tertiary section suggests that only the upper part of Subzone CP1a is sampled here. Unfortunately, the chalky core shattered in Section 605-66-1, 21-23 (Fig. 8; arrow left, enlargement right), and the Cretaceous/Tertiary boundary clay, if originally present, was lost. This would account for the lack of an interval in which $C$. primus is present below the FAD of its evolutionary offspring, C. edwardsii. No major stratigraphic break is evident at this erathem boundary.

The highest occurrence of in situ Cretaceous nannofossils is in Sample 605-66-1, 70-71 cm. The Nephrolithus frequens Zone extends down to Sample 605-67-4, $131-132 \mathrm{~cm}$ and contains an abundant, moderate to well preserved, and diverse coccolith assemblage consisting of over 30 species. These include abundant Arkhangelskiella cymbiformis, Micula decussata, Prediscosphaera cretacea, Watznaueria barnesae, common to abundant Ahmuellerella octoradiata, Cretarhabdus crenulatus, Cribrosphaerella ehrenbergii, Eiffellithus turriseiffeli, E. trabeculatus, Lithraphidites carniolensis, L. quadratus, and Microrhabdulus decoratus. The zonal marker, N. frequens, is rare to common, but consistently present.

The assemblage is little changed in the L. quadratus Zone except that $N$. frequens is absent and Ceratolithoides aculeus is consistently present. Preservation diminishes within this zone, however, becoming poor in Core $605-70$ where the abundance also drops as low as few before reaching high abundances again in Core 71 .

\section{SEDIMENTATION RATES, HIATUSES, AND CORRELATIONS WITH SEISMIC REFLECTION HORIZONS}

As noted above, calcareous nannofossils are not always common and may even be absent over a few short intervals at Sites 604 and 605 . They are in general, however, sufficiently persistent in their occurrence to allow calculations of sedimentation rates by these fossils alone, and to suggest correlations (or lack thereof) of major seismic reflection horizons and oceanographic events with hiatuses. Because the Neogene and Paleogene sections at these two adjacent sites are separated stratigraphically by coalesced disconformities along which the mid-middle Eocene to mid-Miocene sediments have been removed, these sections will be discussed separately.

\section{Neogene Section (Site 604)}

The major reflection horizons are outlined in Figures 3 and 4 (from Wise et al., 1986, figs. 10 and 11). At Site 604 , these consist of local horizons $\mathrm{P}_{1}$ and $\mathrm{P}_{2}$ in the Pliocene-Pleistocene, and $M_{1}$ and $M_{2}$, which bound the upper Miocene section.

\section{Data and Intercorrelations}

Our data are summarized in Figure 9. The sedimentation rate curve, which is uncorrected for compaction, is based on the absolute dates taken from the following: FAD Pseudoemiliania lacunosa (Gartner, 1977); LAD Calcidiscus macintyrei to the LAD of Sphenolithus spp. (Backman and Shackleton, 1983); LAD Discoaster quinqueramus (Muza et al., this volume); Miocene (Berggren et al., 1985).

The highest sedimentation rate in the section (a minimum of $201 \mathrm{~m} / \mathrm{m}$.y.) was calculated for the late Pleistocene (last 0.44 m.y.), a time when sedimentation on the upper rise apparently proceeded without significant interruption following a mid-Pleistocene hiatus. The sedimentation rate for the lower Pleistocene Calcidiscus macintyrei Zone is less than half that rate, about $93 \mathrm{~m} / \mathrm{m}$.y. If this rate is extrapolated up toward the presumed disconformity at the top of the Pseudoemiliania lacunosa Zone, a hiatus representing a maximum of about 0.65 m.y. would have to be assumed to account for missing section and the abbreviated nature of the P. lacunosal small Gephyrocapsa Zones (Fig. 9; Table 1). The assumption of a mid-Pleistocene hiatus and disconformity seems to be supported by the seismic evidence (Figs. 3, 4), where reflection Horizon $\mathrm{P}_{1}$ has been placed at this level $(90 \mathrm{~m}$ sub-bottom; Core 10).

Another hiatus or set of hiatuses is indicated at about $175 \mathrm{~m}$ where the barren and condensed interval discussed in the previous section occurs within the Discoaster brouweri Zone. This includes the barren "unzoned" interval where the Discoaster surculus Subzone (CN12b) is missing in Table 1. This barren interval marks a sharp change in the overall sedimentation rate between the Pleistocene/ upper Pliocene interval $(86 \mathrm{~m} / \mathrm{m} . \mathrm{y}$.) and the lower to mid-Pliocene ( $34 \mathrm{~m} / \mathrm{m}$.y.). If the latter sedimentation rate is extrapolated up to the position of the barren zone, then the nonfossiliferous interval is dated between about 3.3 Ma and 2.4 Ma (not less than $2.35 \mathrm{Ma}$, the extinction of D. misconceptus). If the last occurrence of Discoaster variabilis in Sample 604-19-5, $30 \mathrm{~cm}$ also represents the extinction of that taxon, then the time gap across the unzoned interval can be narrowed to between about 
Table 2B. Distribution of Maestrichtian calcareous nannofossils, Site 605.

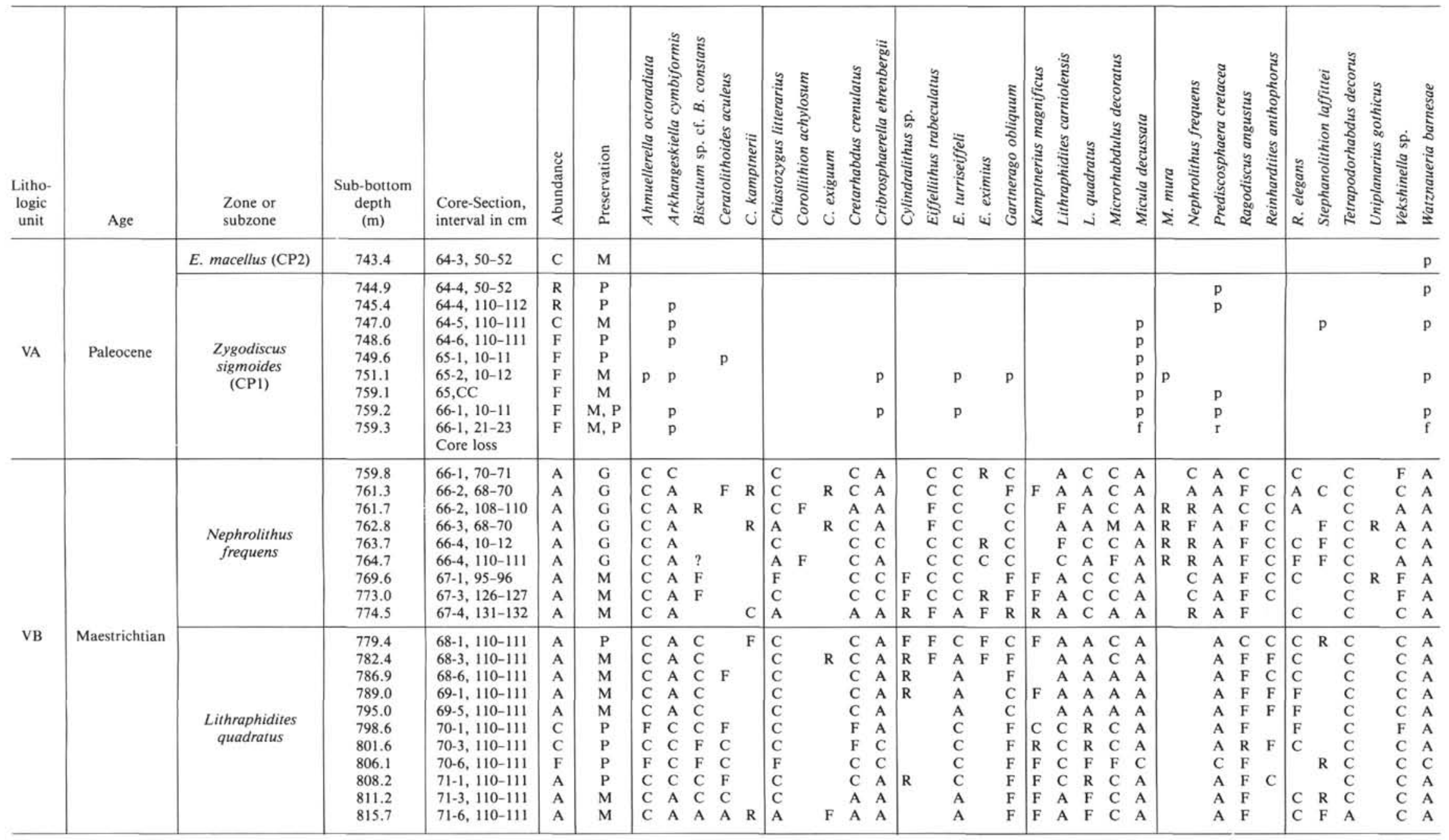

Note: For explanation of symbols, see Table 2A. 


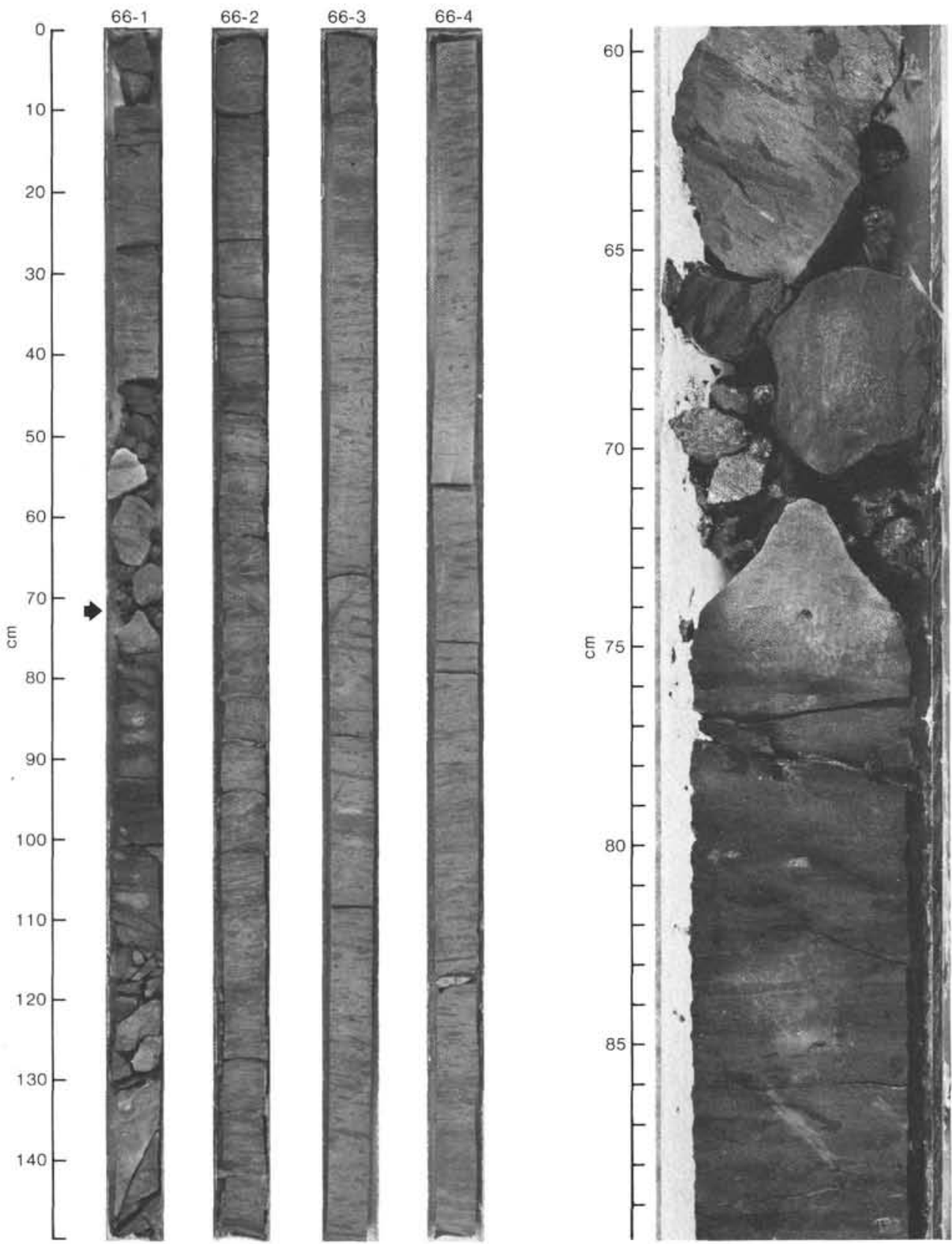

Figure 8. Core 605-66 showing shattered core at the Cretaceous/Tertiary boundary (arrow left, enlargement right). Note absence of appreciable change in shade (color) or in bioturbation pattern on either side of the boundary. There is, however, an increase in silt content above the boundary (see Wise and van Hinte, this volume).

2.4 and 2.9 Ma using the dates of Backman and Shackleton (1983). The barren zone also coincides closely with the depth calculated for the position of seismic reflection Horizon $\mathrm{P}_{2}$, therefore we feel justified in assuming a hiatus at this point.

The next major hiatus is placed at $238.8 \mathrm{~m}$ sub-bottom depth, which coincides with the lithologic boundary that marks the top of the uppermost debris flow of lithostratigraphic Unit III (Fig. 6, arrows). Although the 10 - $\mathrm{m}$ interval above this contact is baren of nannofossils, we can estimate the length of the hiatus by extrapolating the lower Pliocene sedimentation rate down to the contact and by assuming that the entire uppermost debris flow belongs to nannofossil Zone Cn8a, based on the data from Sample 604-26-2, $45 \mathrm{~cm}$. By these criteria, the maximum duration of the niatus would extend from 5.4 to $8.3 \mathrm{Ma}$. We cannot constrain the minimum duration because of the barren interval in Cores 604-24 and -25 . As indicated previously, this hiatus at the top of the debris flows coincides with seismic reflection Horizon $\mathrm{M}_{1}$.

Multiple hiatuses undoubtedly occur within the debris flows. Some of these observed lithologically are shown in Wise et ai. (1986, fig. 14) and in Wise and van 


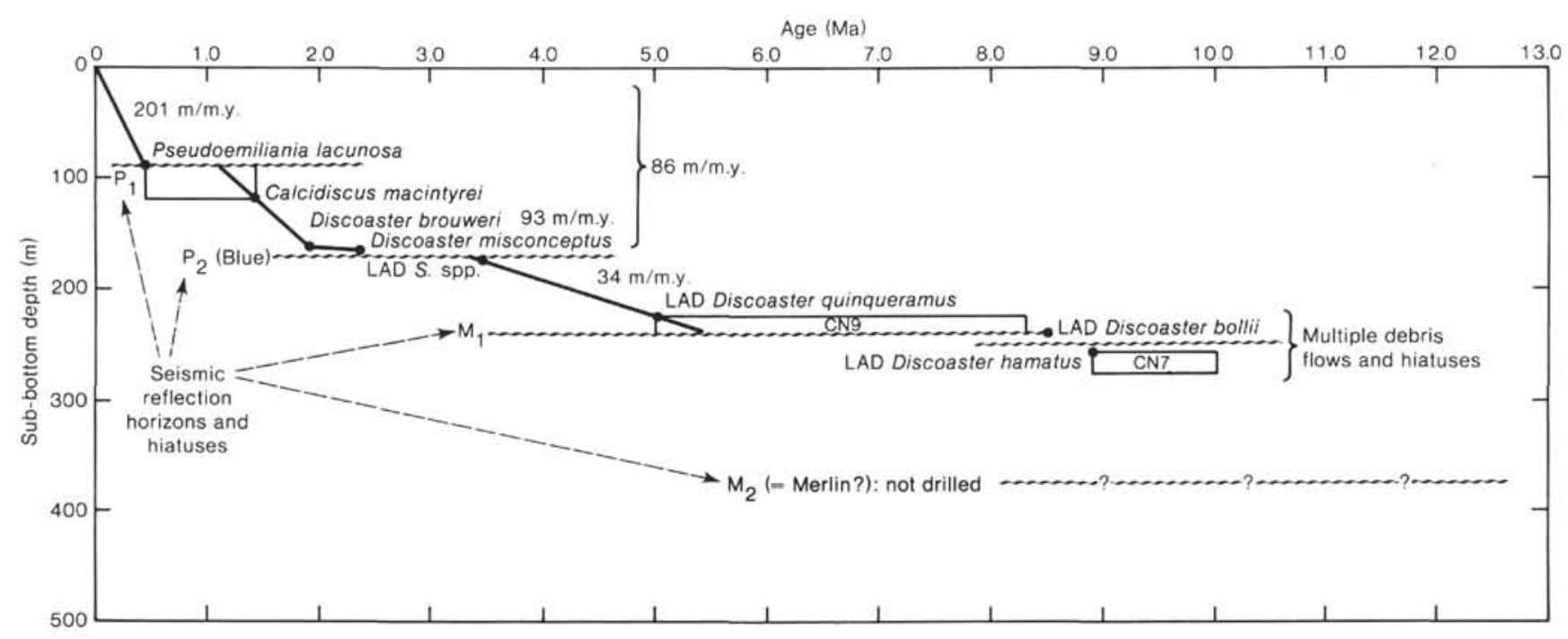

Figure 9. Sedimentation rate diagram for Hole 604 based on nannofossil datums. Hiatuses and correlations with local seismic reflection Horizons $\mathrm{P}_{1}, \mathrm{P}_{2}$, and $\mathrm{M}_{1}$ are indicated; position of Horizon $\mathrm{M}_{2}$ (Merlin?), which was not drilled, is estimated.

Hinte (this volume). We represent only one of these schematically in Figure 7 in order to separate sediments of Zone CN8a from those of CN7, the oldest dated in the hole. Because poor hole conditions forced the abandonment of Site 604 before the base of debris flows could be penetrated, we could not date the initiation of the debris flow events. The seismic analysis (Figs. 3 and 4) suggest that the debris flow package is bounded by a disconformity at about $375 \mathrm{~m}$, which coincides with local seismic reflection Horizon $\mathbf{M}_{2}$. Horizon $\mathbf{M}_{2}$ is turn might be equivalent to the regional Reflector Merlin of Mountain and Tucholke (1985; see alternate correlations and additional discussion by Wise and van Hinte, this volume).

\section{Interpretation}

The composition of the spectacular flows is described in more detail by Wise et al. (1986) and Wise and van Hinte (this volume). The flows contain blocks of Eocene chalk, seen in Figure 6 (Core 604-27), that were eroded from exposed Eocene outcrops updip, some of which are even exposed today (Fig. 2). Also present are cobbles of a variety of ages ranging from early Eocene to middle and late Miocene, some of which contain shallow-water foraminifers and bivalve shell fragments. Angular $\mathrm{Pa}-$ leozoic chert pebbles and rounded mafic or quartz pebbles derived from the Appalachians were also recovered. All of these lithologies suggest a major episode of submarine canyon cutting with the upper rise serving as a locus of deposition for much of the coarser material, deposited either within the canyons themselves or splayed out on a depositional apron.

Active accumulation of canyon fill and/or debris flow material at Site 604 occurred during CN7 and CN8 time (lower Tortonian). The exact time that this deposition began there cannot be determined directly because the lower bounding reflection horizon, $\mathbf{M}_{2}$, was not penetrated and dated. Correlation of this reflector, however, with the regional Reflector Merlin of Mountain and Tu- cholke, suggests that canyon cutting began in earnest around the middle/late Miocene boundary (Mountain and Tucholke, 1985; Wise et al., 1986). The debris flows ended at Site 604 prior to the end of the Miocene, perhaps during Zone $\mathrm{CN} 9$ time (probably prior to the Messinian).

The canyon-cutting events outlined above appear to correlate closely with major depositional changes recorded on the lower continental rise at DSDP Site 603 (Muza et al., this volume). There Horizon $\mathrm{M}_{2}$ (Merlin) is marked by a disconformity between nannofossil Zones $\mathrm{CN} 6$ and $\mathrm{CN} 7 \mathrm{~b}$, which gives it a maximum age of between 10.5 and $10.8 \mathrm{Ma}$. As is probably the case at Site 604 , the upper part of Subzone CN8a appears to be missing because of a hiatus, but sedimentation above this disconformity at Site 603 during Zone CN8b time is exceptionally high $(192 \mathrm{~m} / \mathrm{m} . \mathrm{y}$.$) , indicating that the lower rise was$ receiving enormous amounts of fine-grained erosional products that were being introduced into the deep-sea environment during the canyon cutting along the slope and shelf. From Zone CN9 time onward (late Tortonian-early Messsinian), however, sedimentation rates on the lower rise decrease, although they are quite uniform (87 $\mathrm{m} / \mathrm{m} . \mathrm{y}$.), indicating a lower but quite steady input of fine sediments.

The nannofossil records from Sites 604 and 603 together tend to constrain the major canyon-cutting events on the slope/outer shelf (with concomitant high sedimentation rates on the lower rise) to the early Tortonian (i.e., earliest late Miocene time). According to Berggren et al. (1985), this late CN6 through CN8 time interval would correspond to 10.5 to $8.3 \mathrm{Ma}$. By Messinian times (latest Miocene), sedimentation on the lower rise had dropped to a much lower rate, which remained essentially constant thereafter. On the upper rise, sedimentation reverted primarily to the deposition of fine-grained clastics, indicating that the canyon-cutting event was over.

This evidence from the New Jersey Transect becomes highly significant for interpretations of sea-level history, 
because it indicates strongly that the major sea-level drop following the mid-Miocene high (Vail Cycle TM2.2) was in the early Tortonian, not during the Messinian as often assumed. The maximum Miocene low stand, therefore, correlates with Vail Cycle TM3.1, not Cycle TM3.2 as originally published (Vail et al., 1977, 1980). Our data are in accord with new interpretations by sea-level specialists, also based on drill and seismic data from the New Jersey margin, which place the late Miocene low stand at Cycle TM3.1 (P. R. Vail, personal communication, 1986; Greenlee et al., in press).

The cause of the early Tortonian sea-level low stand is the subject of some speculation. We argue here and elsewhere in this volume (Muza et al.; Wise and van Hinte, both this volume) for a glacio-eustatic mechanism. The time interval in question (about 10.5 to $8.3 \mathrm{Ma}$ or slightly younger at Site 604) clearly postdates the initiation of ice cap formation on East Antarctica (about $14 \mathrm{Ma}$, according to Kennett, 1978). It coincides, however, with events believed to be associated with the formation of the West Antarctic Ice Sheet.

As summarized by Wise et al. (1985) for the Southern Ocean, Ciesielski and Weaver (1983) documented major abyssal erosion in regions are far north as the Falkland Plateau and beyond (DSDP Site 513), occurring by the early late Miocene (prior to 9.5 or $10.0 \mathrm{Ma}$ ). This was followed by the initiation of ice rafting at these relatively lower latitudes (lower, that is, compared to the Antarctic continental margin) by $8.7 \mathrm{Ma}$. Ciesielski and Weaver (1983) consider this event indicative of the establishment of large Antarctic ice shelves. This in turn probably led for the first time to the establishment of a grounded West Antarctic Ice Sheet. At this point, ice formation on Antarctica was at a maximum, not to be exceeded later until the development of Northern Hemisphere continental glaciation during the Pliocene-Pleistocene. According to the record from the Southern Ocean, then, it was during the Tortonian that the greatest and most rapid drop in sea level should have occurred. The record from Sites 604 and 603 seems to bear out this prediction, with evidence in the way of scour zones from the lower rise to the upper rise (reflection Horizon $\mathbf{M}_{2}$ ), multiple debris flows of early Tortonian age, and exceptionally high sedimentation rates on the lower rise (at least during $\mathrm{CN} 8 \mathrm{~b}$ time).

The Pliocene hiatus delineated in Figure 7 is correlative with reflection Horizon $\mathrm{P}_{2}$, and is dated by nannofossils from about 2.4 Ma (not less than $2.35 \mathrm{Ma}$ ) to 2.9 (minimum) or 3.3 Ma (maximum). Backman (1979) dated a similar hiatus at DSDP Hole 111A (Orphan Knoll); he attributed it to increased bottom-current velocities that resulted from increased bottom-water formation in response to the closure of the Central American Seaway. $\mathrm{He}$ also suggested that this closure could have triggered the onset of the Labrador Current. Such a reorganization of current regimes could have caused the hiatus at Site 604 as well. On the other hand, this hiatus could represent the onset of Northern Hemisphere continental glaciation, which Backman (1979) and Shackleton et al. (1984) date at about 2.4 or $2.5 \mathrm{Ma}$. The onset of such an event might have triggered current erosion along the up- per rise, thereby removing part of the sedimentary record before $2.4 \mathrm{Ma}$. This would require the removal of at least $25 \mathrm{~m}$ of sediment to produce the observed hiatus at Site 604 (assuming deposition had occurred there at the preglacial rate of $34 \mathrm{~m} / \mathrm{m} . \mathrm{y}$.).

In any event, Horizon $\mathrm{P}_{2}$ appears to correspond to Reflector Blue of Mountain and Tucholke (1985), which they map throughout the continental rise of this region and to the south along the Blake Outer Ridge and Ba$\sin$. They rather unequivocally attribute it to a major pulse of intensified bottom currents linked to the onset of North American glaciation. The hiatus associated with Reflector Blue, however, was not detected at Site 603 (Muza et al., this volume) where sedimentation rates did not change appreciably during the Pliocene. At Site 604, however, the preglacial Pliocene rates below Horizon $\mathrm{P}_{2}$, or Blue, are only about a third those of the postglacial Pliocene, which lies above that boundary.

\section{Paleogene Section (Site 605)}

The major reflection horizons for the Paleogene of Site 605 are shown in Figures 3 and 4, and consist of $A^{c}$, $A^{52}$, and $A^{*}$. Our data are given in Figure 10, which includes datums from the middle to lower Eocene (from Applegate and Wise, this volume) as well as the Paleocene (this chapter). The time scale is from Berggren et al. (1985). We should note that the discussion of sedimentation rates below is highly dependent on the accuracy of this time scale, particularly where condensed intervals and hiatuses are delineated.

The sedimentation rate for the Eocene portion of the section down to the FAD of Discoaster lodoensis is $37 \mathrm{~m} /$ m.y. There is no hiatus in the vicinity of Horizon $A^{c}$ at about $350 \mathrm{~m}$, nor is one expected, because that is a diagenetic boundary that is probably time transgressive to some extent. The sedimentation rate drops to a minimum of $8 \mathrm{~m} / \mathrm{m}$.y. in the basal Eocene Zone CP9, which appears to represent a condensed interval. Seismic reflection Horizon $\mathrm{A}^{52}$ is placed at about $525 \mathrm{~m}$, or near the top of this condensed interval.

We suspect a hiatus near the base of Zone CP9. It may lie at a break not far below the nannofossil Eocene/ Paleocene boundary visible in Section 605-44-5 (Fig. 11; arrow left, enlargement right). Zone CP8 is over $40 \mathrm{~m}$ thick, and we presume that the sedimentation rate there approached the average for the Eocene section $(37 \mathrm{~m} /$ m.y.), because the error box constructed around the zone (Fig. 10) would not allow it to be much less than that. The rate for Zones CP7 and CP6, however, is much lower. These represent another condensed interval.

The sedimentation rate for the well-dated interval across the Heliolithus kleinpellii and Fasciculithus tympaniformis zones (CP5 and CP4), however, is quite high $(67 \mathrm{~m} /$ m.y.). Interestingly, Zone CP5 is particularly well represented in some wells of the New Jersey coastal plain (Jiang and Wise, this volume), where it denotes a prominent Paleocene transgression and sea-level high stand (Olsson and Wise, this volume).

The prominent disconformity that spans most of Zones CP3 and CP2 is conspicuous in the core photographs (Fig. 7; arrow left, enlargement right). By extrapolating 


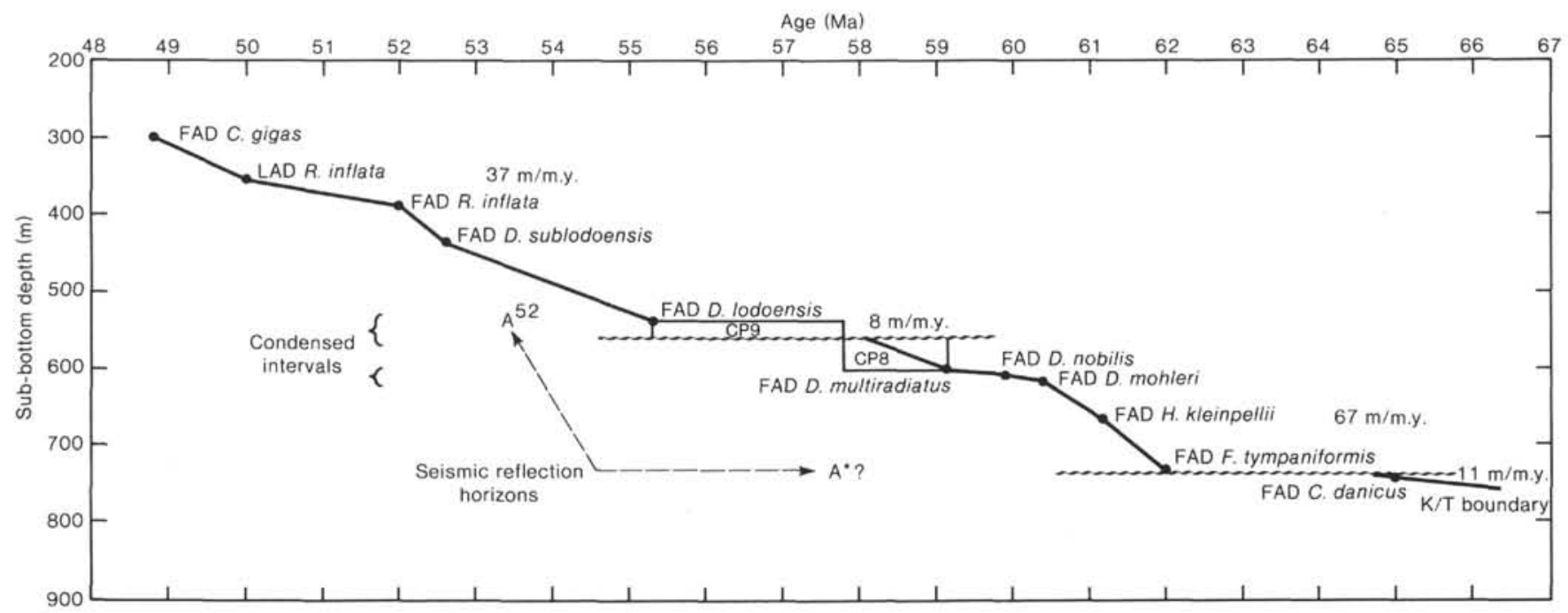

Figure 10. Sedimentation rate diagram for Hole 605 based on nannofossil datums. Hiatuses and correlations with seismic reflection Horizons $\mathrm{A}^{52}$ and $A^{*}$ ? are indicated. Eocene datums are from Applegate and Wise (this volume). $K / T$ is Cretaceous/Tertiary boundary. Condensed intervals indicated by braces; the upper interval coincides with Horizon $\mathrm{A}^{52}$.

the sedimentation rates from above and below the hiatus, we estimate the duration of the hiatus at $2.6 \mathrm{~m} . \mathrm{y}$. (from 62.1 to $64.7 \mathrm{Ma}$ ). This disconformity removed the upper Danian sediment beginning essentially at the $\mathrm{Da}$ nian/Selandian (lower/upper Paleocene) boundary. The hiatus corresponds to the major sea-level drop at the base of Vail Cycle TE2.1 (Vail et al., 1977), and can be correlated with seismic reflection Horizon A* in Figures 3 and 4 . This is an especially strong reflection traceable along the New Jersey shelf, slope, and upper rise. Whether it actually corresponds to Horizon $\mathrm{A}^{*}$ of the North American Basin is not clear, therefore, we label it Horizon $A^{*}$ ? in Figure 10, and in the regional synthesis by Olsson and Wise (this volume). Olsson and Wise (this volume) relate this sequence at Site 605 and those of the New Jersey Coastal Plain to sea-level changes and to the Vail et al. $(1977,1980)$ cycles, therefore, we refer the reader to their chapter for more detailed discussion and analysis of this aspect of the study.

As noted in Figure 10, the sedimentation rate through Zone CP1 below the Danian hiatus is considerably lower than that above, only $11 \mathrm{~m} / \mathrm{m}$.y. This low rate can be attributed to the reduced productivity of biogenic carbonate that followed the terminal Cretaceous mass extinctions of calcareous nannoplankton. Even this sedimentation rate, however, is high for a Paleocene DSDP section. Indeed, the length of this remarkably long (200-m) Paleocene section is attributed to its continental margin site of deposition, which is favorably located well above the carbonate compensation depth and close to sources of fine-grained clastic sediment.

As the uppermost Maestrichtian Nephrolithus frequens Zone spans a full $14.7 \mathrm{~m}$ of section in this hole, we see little evidence of a stratigraphic break at the Cretaceous/ Tertiary boundary. Although the core shattered at this point (Fig. 9), this could have resulted from a washout during drilling if a boundary clay had been present. At this point during the drilling of this single-bit hole $(760 \mathrm{~m})$, the core being cut was quite thin because the roller cones on the bit were worn and loose; therefore, a poorly unconsolidated interval would likely have been lost.

\section{ACKNOWLEDGMENTS}

We are pleased to acknowledge the critical and detailed reviews by Dr. Merton E. Hill, III, and Mr. Mark Filewicz (Union Oil Co., California). Dr. P. R. Vail (Exxon Production Research Co., Houston) provided helpful discussions on coastal onlap-offlap cycles. We thank our colleague Mr. Joseph E. Applegate for providing the Eocene data for a sedimentation rate diagram (Fig. 10), and Mssrs. Wuchang Wei, Yan Wen Jiang, J. E. Applegate, John Firth, and Paul Hansard for plotting abundances of specimens for Zone CP8 (as part of a graduate nannofossil class project). Mr. James R. Breza prepared the samples, and he and Wuchang Wei helped prepare the manuscript. Laboratory facilities were supported in part by NSF Grant DPP 84-14268 and an equipment grant from the AMOCO Foundation.

\section{REFERENCES}

Backman, J., 1979. Pliocene biostratigraphy of DSDP Sites 111 and 116 from the North Atlantic Ocean and the age of Northern Hemisphere glaciation. Acta Univ. Stockh., Stockh. Contr. Geol., 32: $115-137$.

Backman, J., and Shackleton, N. S., 1983. Quantitative biochronology of Pliocene and early Pleistocene calcareous nannofossils from the Atlantic, Indian, and Pacific oceans. Mar. Micropaleontol., 8: 141-170.

Bergen, J. A., 1984. Calcareous nannoplankton from Deep Sea Drilling Project Leg 78A: evidence for imbricate underthrusting at the Lesser Antillian active margin. In Biju-Duval, B., Moore, J. C., et al., Init. Repts. DSDP, 78A: Washington (U.S. Govt. Printing Office), 411-445.

Berggren, W. A., Kent, D. V., Flynn, J. J., and Van Couvering, J. A., 1985. Cenozoic geochronology. Geol. Soc. Am. Bull., 96:14071418.

Bukry, D., 1985. Mid-Atlantic Ridge coccolith and silicoflagellate biostratigraphy, Deep Sea Drilling Project Sites 558 and 563. In Bougault, H., Cande, S. W., et al., Init. Repts. DSDP, 82: Washington (U.S. Govt. Printing Office), 591-603.

Čepek, P., and Hay, W. W., 1969. Calcareous nannoplankton and biostratigraphic subdivision of the Upper Cretaceous. Trans. Gulf Coast Assoc. Geol. Soc., 19:323-336.

Ciesielski, P. F., and Weaver, F. M., 1983. Neogene and Quaternary paleoenvironmental history of Deep Sea Drilling Project Leg 71 sediments, Southwest Atlantic Ocean. In Ludwig, W. J., Krashen- 
innikov, V. A., et al., Init. Repts. DSDP, 71, Pt. 2: Washington (U.S. Govt. Printing Office), 461-477.

Gartner, S., 1977. Calcareous nannofossil biostratigraphy and revised zonation of the Pleistocene. Mar. Micropaleontol., 2:1-25.

Greenlee, S. M., Schroeder, F. W., and Vail, P. R., in press. Seismic stratigraphic and geohistory analysis of Tertiary strata from the continental shelf off New Jersey-calculation of eustatic fluctuations from stratigraphic data. Geol. Soc. Am. Decade N. Am. Geol. Project.

Hay, W. W., 1970. Calcareous nannofossils from cores recovered on Leg 4. In Bader, R. G., Gerard, R. D., et al., Init. Repts. DSDP, 4: Washington (U.S. Govt. Printing Office), 455-501.

Heck, S. E. van, 1979a. Bibliography and taxa of calcareous nannoplankton. Int. Nannoplankton Assoc. Newsl., 1:AB1-5, A1-12, B127.

1979b. Bibliography and taxa of calcareous nannoplankton. Int. Nannoplankton Assoc. Newsl., 1:AB VI, A13-28, B28-42. $1980 \mathrm{a}$. Bibliography and taxa of calcareous nannoplankton. Int. Nannoplankton Assoc. Newsl., 2:5-34.

$1980 \mathrm{~b}$. Bibliography and taxa of calcareous nannoplankton. Int. Nannoplankton Assoc. Newsl., 2:43-81. 1981a. Bibliography and taxa of calcareous nannoplankton. Int. Nannoplankton Assoc. Newsl., 3:4-41. 1981b. Bibliography and taxa of calcareous nannoplankton. Int. Nannoplankton Assoc. Newsl., 3:51-86.

1982a. Bibliography and taxa of calcareous nannoplankton. Int. Nannoplankton Assoc. Newsl., 4:7-50.

1982b. Bibliography and taxa of calcareous nannoplankton. Int. Nannoplankton Assoc. Newsl., 4:65-96.

1983. Bibliography and taxa of calcareous nannoplankton. Int. Nannoplankton Assoc. Newsl., 5:4-13.

Kennett, J. P., 1978. The development of planktonic biogeography in the Southern Ocean during the Cenozoic. Mar. Micropaleontol., 3:301-345.

Lang, T. H., and Watkins, D. K., 1984. Cenozoic calcareous nannofossils from DSDP Leg 77. In Buffler, R. T., Schlager, W., et al., Init. Repts. DSDP, 77: Washington (U.S. Govt. Printing Office), 629-648.

Loeblich, A. R., Jr., and Tappan, H., 1966. Annotated index and bibliography of the calcareous nannoplankton, I. Phycologia, 5:81216.

, 1968. Annotated index and bibliography of the calcareous nannoplankton, II. J. Paleontol., 42:584-598.

,1969. Annotated index and bibliography of the calcareous nannoplankton, III. J. Paleontol., 43:568-588

1970a. Annotated index and bibliography of the calcareous nannoplankton, IV. J. Paleontol., 44:558-574.

,1970b. Annotated index and bibliography of the calcareous nannoplankton, V. Phycologia, 9:157-174.

, 1971. Annotated index and bibliography of the calcareous nannoplankton, VI. Phycologia, 10:315-339.

1973. Annotated index and bibliography of the calcareous nannoplankton, VII. J. Paleontol., 47:715-759.

Mountain, G. S., and Tucholke, B. E., 1985. Mesozoic and Cenozoic stratigraphy of the United States Atlantic continental slope and rise. In Poag, C. W. (Ed.), Geologic Evolution of the United States Atlantic Margin: Stroudsburg, PA (Van Nostrand-Reinhold), pp. 293-341.
Okada, H., and Bukry, D., 1980. Supplementary modification and introduction of code numbers to the low-latitude coccolith biostratigraphic zonation (Bukry, 1973; 1975). Mar. Micropaleontol., 5:321325.

Perch-Nielsen, K., 1985. Cenozoic calcareous nannofossils. In Bolli, H. M., Saunders, J. B., and Perch-Nielsen, K. (Eds.), Plankton Stratigraphy: Cambridge (Cambridge University Press), pp. 427554.

Robb, J. M., Hampson, J. C., Jr., and Kirby, J. R., 1982. Surficial geologic studies of the continental slope in the Northern Baltimore Canyon Trough area-techniques and findings. Proc. 14th Ann. Offshore Tech. Conf., Houston, Texas, Paper OTC 4170, pp. 39-43.

Robb, J. M., Hampson, J. C., Jr., Kirby, J. R., and Twichell, D. C., 1981. Geology and potential hazards of the Continental Slope between Lindenkohl and South Toms canyons offshore mid-Atlantic United States. U.S. Geol. Surv. Open File-Rept., 81-600.

Romein, A. J. T., 1979. Lineages in early Paleogene calcareous nannoplankton. Utrecht Micropalaeontol. Bull., 22:1-231.

Shackleton, N. J., Backman, J., Zimmerman, H., Kent, D. V., Hall, M. A., Roberts, D. G., et al., 1984. Oxygen isotope calibration of the onset of ice-rafting and history of glaciation in the North Atlantic region. Nature, 307:620-623.

Steinmetz, J. C., 1984a. Bibliography and taxa of calcareous nannoplankton-III. Int. Nannoplankton Assoc. Newsl., 6:6-37. 1984b. Bibliography and taxa of calcareous nannoplankton-IV. Int. Nannoplankton Assoc. Newsl., 6:55-81. 1985. Bibliography and taxa of calcareous nannoplanktonV. Int. Nannoplankton Assoc. Newsl., 7:5-28.

Theodoridis, S., 1984. Calcareous nannofossil biozonation of the Miocene and revision or the helicoliths and discoasters. Utrecht Micropaleontol. Bull., 32:1-271.

Vail, P. R., Mitchum, R. M., Jr., Shipley, T. H., and Buffler, R. T., 1980. Unconformities of the North Atlantic. R. Soc. London Phil. Trans., 294:137-155.

Vail, P. R., Mitchum, R. M., Jr., Todd, R. G., Widmier, J. M., Thompson, S., III, Sangree, J. B., Bubb, J. N., and Hatlelid, W. G., 1977. Seismic stratigraphy and global changes of sea level. In Payton, C. E. (Ed.), Seismic Stratigraphy-Applications to Hydrocarbon Exploration. Am. Assoc. Petrol. Geol. Mem., 26:49-212.

Wise, S. W., Gombos, A. M., and Muza, J. P., 1985. Cenozoic evolution of polar water masses, southwest Atlantic Ocean. In Hsü, K. J., and Weissert, H. J. (Eds.), South Atlantic Paleoceanography: Cambridge (University Press), pp. 283-324.

Wise, S. W., van Hinte, J. E., Mountain, G. S., Biart, B. N. M., Covington, J. M., Drugg, W. S., Dunn, D. A., Farre, J., Habib, D., Hart, M. B., Haggerty, J. S., Johns, M. W., Lang, T. H., Meyers, P. A., Miller, K. G., Moullade, M. R., Muza, J. P., Ogg, J. G., Okamura, M., Sarti, M., and von Rad, U., 1986. Mesozoic-Cenozoic clastic depositional environments revealed by DSDP Leg 93 drilling on the continental rise off the eastern United States. In Summerhayes, C. P. and Shackleton, N. J. (Eds.), North Atlantic Palaeoceanography. Geol. Soc. London Spec. Publ., 21:35-66.

Date of Initial Receipt: 30 July 1985 Date of Acceptance: 12 August 1986 

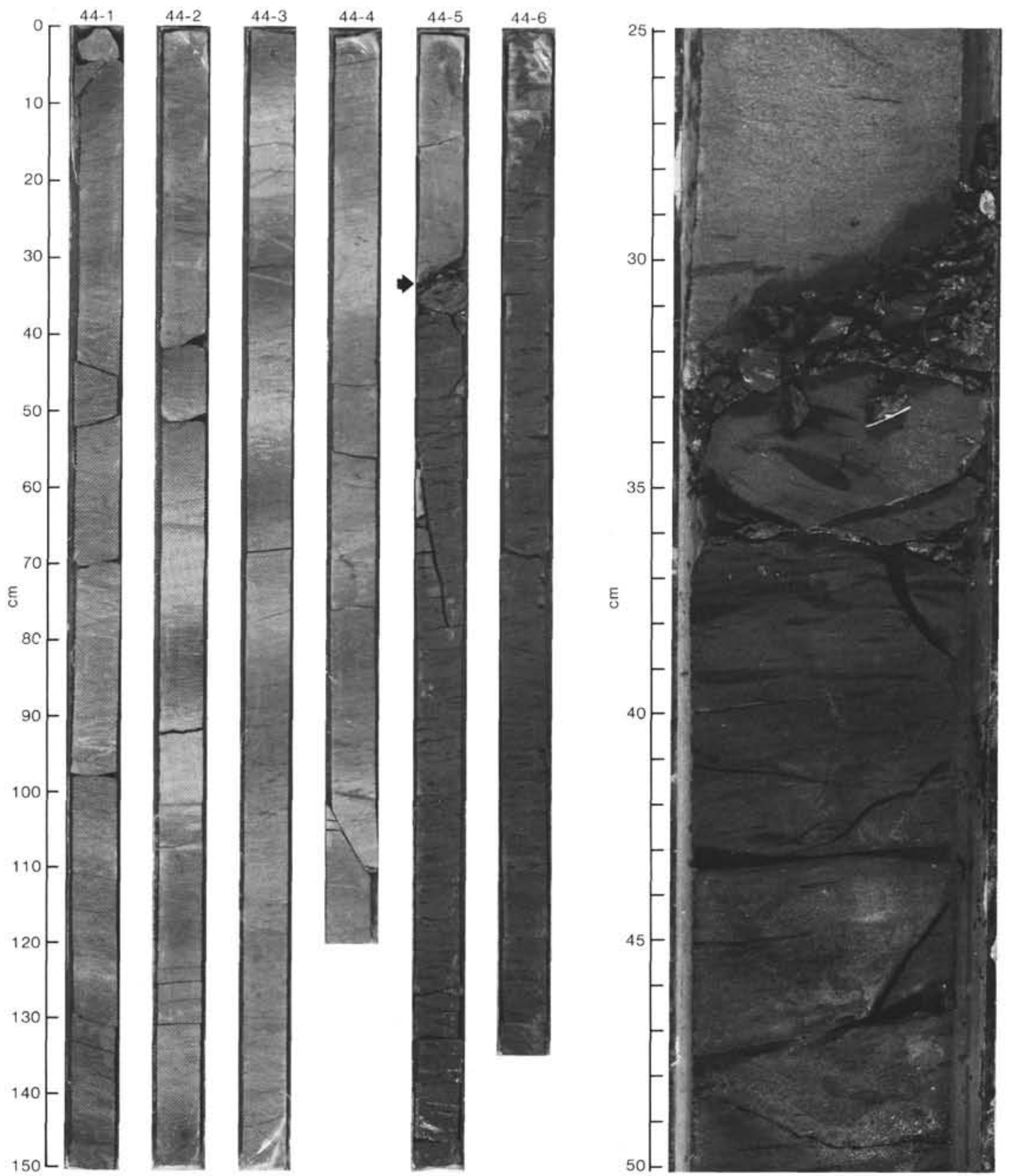

Figure 11. Core 605-44 showing break in core (arrow left, enlargement right), which may represent a disconformity close to the Eocene/Paleocene boundary. The nannofossil Eocene/Paleocene boundary is placed between Sections 605-44-1 and 605-44-2. Note change in shade (color) and bioturbation pattern either side of the break.

\section{APPENDIX A}

Nannofossil Species Considered for Site 604

Amaurolithus amplificus (Bukry and Percival) Gartner and Bukry, 1975 Amaurolithus delicatus Gartner and Bukry, 1975

Amaurolithus primus (Bukry and Percival) Gartner and Bukry, 1975 Amaurolithus tricorniculatus (Gartner) Gartner and Bukry, 1975

Braarudosphaera bigelowii (Gran and Braarud) Deflandre, 1947

Calcidiscus leptoporus (Murray and Blackman) Loeblich and Tappan, 1978

Calcidiscus macintyrei (Bukry and Bramlette) Loeblich and Tappan, 1978

Campylosphaera dela (Bramlette and Sullivan) Hay and Mohler, 1967 Campylosphaera eodela Bukry and Percival, 1971

Catinaster calyculus Bramlette and Martini, 1963

Ceratolithus acutus Gartner and Bukry, 1974
Ceratolithus cristatus Kamptner, 1950

Ceratolithus separatus Bukry, 1979

Coccolithus formosus (Kamptner) Wise, 1973

Coccolithus pelagicus (Wallich) Schiller, 1930

Chiasmolithus grandis (Bramlette and Riedel) Rodomski, 1968

Chiasmolithus oamaruensis (Deflandre) Hay, Mohler, and Wade, 1966

Chiasmolithus solitus (Bramlette and Sullivan) Locker, 1968

Clausicoccus fenestratus (Deflandre and Fert) Prins, 1979

Coronocyclus nitescens (Kamptner) Bramlette and Wilcoxon, 1967

Crenalithus doronicoides (Black and Barnes) Roth, 1973

Cricolithus jonesii Cohen, 1964

Cyclicargolithus floridanus (Roth and Hay in Hay et al.) Bukry, 1971

Discoaster asymmetricus Gartner, 1969

Discoaster barbadiensis Tan, 1927

Discoaster bellus Bukry and Percival, 1971

Discoaster berggrenii Bukry, 1971 
Discoaster bifax Bukry, 1971

Discoaster binodosus Martini, 1958

Discoaster bollii Martini and Bramlette, 1963

Discoaster brouweri Tan, 1927

Discoaster calcaris Gartner, 1967

Discoaster challengeri Bramlette and Riedel, 1954

Discoaster deflandrei Bramlette and Riedel, 1954

Discoaster elegans Bramlette and Sullivan, 1961

Discoaster hamatus Martini and Bramlette, 1963

Discoaster intercalaris Bukry, 1971

Discoaster misconceptus (Theodoridis) Muza, Wise, and Covington, this volume

Discoaster neohamatus Bukry and Bramlette, 1969

Discoaster pentaradiatus Tan, 1927

Discoaster quinqueramus Gartner, 1969

Discoaster saipanensis Bramlette and Riedel, 1954

Discoaster surculus Bramlette and Martini, 1963

Discoaster tamalis Kamptner, 1967

Discoaster tanii Bramlette and Riedel, 1954

Discoaster triradiatus Tan, 1927

Discoaster variabilis Bramlette and Martini, 1963

Gephyrocapsa caribbeanica Boudreaux and Hay, 1967

Gephyrocapsa oceanica Kamptner, 1943

Helicosphaera carteri (Wallich) Kamptner, 1954

Helicosphaera compacta Bramlette and Wilcoxon, 1967

Helicosphaera intermedia Martini, 1965

Helicosphaera sellii (Bukry and Bramlette) Jafar and Martini, 1975

Isthmolithus recurvus Deflandre in Deflandre and Fert, 1954

Lanternithus minutus Stradner, 1962

Leptodiscus larvalis Bukry and Bramlette, 1969

Lophodolithus mochlophorus Deflandre in Deflandre and Fert, 1954

Micrantholithus aequalis Perch-Nielsen, 1971

Neochiastozygus junctus (Bramlette and Sullivan) Perch-Nielsen, 1971

Neococcolithes dubius (Deflandre) Black, 1967

Pontosphaera anisotrema (Kamptner) Backman, 1980

Pontosphaera distincta (Bramlette and Sullivan) Roth and Thierstein, 1972

Pontosphaera japonica (Takayama) Nishida, 1973

Pontosphaera multipora (Kamptner) Roth, 1970

Pontosphaera ocellata (Bramlette and Sullivan) Perch-Nielsen, 1984

Pontopshaera pectinata (Bramlette and Sullivan) Sherwood, 1974

Pontosphaera plana (Bramlette and Sullivan) Haq, 1971

Pontosphaera pulcher (Deflandre in Deflandre and Fert) Romein, 1979

Pseudoemiliania lacunosa (Kamptner) Gartner, 1969

Pyrocyclus orangensis (Bukry) Backman, 1980

Reticulofenestra bisectus (Hay, Mohler, and Wade) Roth, 1970

Reticulofenestra pseudoumbilica (Gartner) Gartner, 1969

Reticulofenestra reticulata (Gartner) Roth and Thierstein, 1972

Reticulofenestra scrippsae Bukry and Percival, 1971

Reticulofenestra umbilica (Levin) Martini and Ritzkowski, 1968

Rhabdosphaera clavigera Murray and Blackman, 1898

Rhabdosphaera inflata Bramlette and Sullivan, 1961

Rhabdosphaera stylifera Lohmann, 1902

Rhabdosphaera tenuis Bramlette and Sullivan, 1961

Scapholithus fossilis Deflandre in Deflandre and Fert, 1954

Scyphosphaera globulata Bukry and Percival, 1971

Scyphosphaera pulcherrima Deflandre, 1942

Scyphosphaera recurvata Deflandre, 1942

Sphenolithus moriformis (Brönnimann and Stradner) Bramlette and Wilcoxon, 1967

Syracosphaera pulchra Lohmann, 1902

Triquetrorhabdulus rugosus Bramlette and Wilcoxon, 1967

Umbilicosphaera cricota (Gartner) Cohen and Reinhardt, 1968

Umbilicosphaera sibogae (Weber-van Bosse) Gaarder, 1970

Zygrhablithus bijugatus (Deflandre in Deflandre and Fert) Deflandre, 1959

\section{APPENDIX B}

\section{Nannofossil Species Considered for Site 605}

\section{Tertiary Species}

Biscutum constans (Gorka) Black in Black and Barnes, 1959 Braarudosphaera bigelowii (Gran and Braarud) Deflandre, 1947 Campylosphaera dela (Bramlette and Sullivan) Hay and Mohler, 1967 Campylosphaera eodela Bukry and Percival, 1971

Chiasmolithus bidens (Bramlette and Sullivan) Hay and Mohler, 1967
Chiasmolithus californicus (Sullivan) Hay and Mohler, 1967

Chiasmolithus consuetus (Bramlette and Sullivan) Hay and Mohler, 1967

Chiasmolithus danicus (Brotzen) Hay and Mohler, 1967

Coccolithus cavus Hay and Mohler, 1967

Coccolithus pelagicus (Wallich) Schiller, 1930

Cruciplacolithus edwardsii Romein, 1979

Cruciplacolithus primus Perch-Nielsen, 1977

Cruciplacolithus tenuis (Stradner) Hay and Mohler in Hay et al., 1967

Cyclagelosphaera reinhardtii (Perch-Nielsen) Romein, 1977

Discoaster bramlettei (Bukry and Percival) Romein, 1979

Discoaster mediosus Bramlette and Sullivan, 1961

Discoaster mohleri (Stradner) Bukry and Percival, 1971

Discoaster multiradiatus Bramlette and Riedel, 1954

Discoaster nobilis Martini, 1961

Discoaster splendidus Martini, 1960

Ellipsolithus distichus (Bramlette and Sullivan) Sullivan, 1964

Ellipsolithus macellus (Bramlette and Sullivan) Sullivan, 1964

"Ericsonia" robusta (Bramlette and Sullivan) Perch-Nielsen, 1977

"Ericsonia" subpertusa Hay and Mohler, 1967

Fasciculithus involutus Bramlette and Sullivan, 1961

Fasciculithus schaubii Hay and Mohler, 1967

Fasciculithus tympaniformis Hay and Mohler in Hay et al., 1967

Heliolithus kleinpellii Sullivan, 1964

Markalius apertus Perch-Nielsen, 1979

Markalius inversus (Deflandre in Deflandre and Fert) Bramlette and Martini, 1964

Neochiastozygus concinnus (Martini) Perch-Nielsen, 1971

Neochiastozygus distentus (Bramlette and Sullivan) Perch-Nielsen, 1971

Neochiastozygus junctus (Bramlette and Sullivan) Perch-Nielsen, 1971

Prinsius bisulcus (Stradner) Hay and Mohler, 1967

Prinsius dimorphosus (Perch-Nielsen) Perch-Nielsen, 1977 (types 1 and 2 of Romein, 1979)

Sphenolithus primus Perch-Nielsen, 1971

Toweius craticulus Hay and Mohler, 1967

Toweius eminens (Bramlette and Sullivan) Perch-Nielsen, 1971

Zygodiscus adamas Bramlette and Sullivan, 1971

Zygodiscus sigmoides Bramlette and Sullivan, 1961

Zygodiscus spiralis Bramlette and Martini, 1964

Zygrhablithus bijugatus (Deflandre in Deflandre and Fert) Deflandre, 1959

\section{Cretaceous Species}

Ahmuellerella octoradiata (Gorka) Reinhardt, 1964

Arkhangelskiella cymbiformis Vekshina, 1959

Biscutum sp. cf. B. constans (Gorka) Black in Black and Barnes, 1959

Ceratolithoides aculeus (Stradner) Prins and Sissingh in Sissingh, 1977

Ceratolithoides kamptneri Bramlette and Martini, 1964

Chiastozygus litterarius (Gorka) Manivit, 1971

Corollothion achylosum (Stover) Thierstein, 1971

Corollithion exiguum Stradner, 1961

Cretarhabdus crenulatus Bramlette and Martini, 1964

Cribrosphaerella ehrenbergii (Arkhangelsky) Deflandre in Piveteau, 1952

Eiffellithus trabeculatus (Gorka) Reinhardt and Gorka, 1967

Eiffellithus turriseiffeli (Deflandre in Deflandre and Fert) Reinhardt, 1965

Eiffellithus eximius (Stover) Perch-Nielsen, 1968

Gartnerago obliquum (Stradner) Reinhardt, 1970

Kamptnerius magnificus Deflandre, 1959

Lithraphidites carniolensis Deflandre, 1963

Lithraphidites quadratus Bramlette and Martini, 1964

Microrhabdulus decoratus Deflandre, 1959

Micula decussata Vekshina, 1959

Micula mura (Martini) Bukry, 1963

Nephrolithus frequens Gorka, 1957

Prediscosphaera cretacea (Arkhangelsky) Gartner, 1968

Ragodiscus angustus (Stradner) Reinhardt, 1971

Reinhardtites anthophorus (Deflandre) Perch-Nielsen, 1968

Reinhardtites elegans (Gartner) Wise, 1983

Stephanolithion laffittei Noel, 1957

Tetrapodorhabdus decorus (Deflandre in Deflandre and Fert) Wind and Wise, 1977

Uniplanarius gothicus (Deflandre) Hattner and Wise in Wind and Wise, 1983

Watznaueria barnesae (Black in Black and Barnes) Perch-Nielsen, 1968 